\title{
OPEN Biophysical characterization of the inactivation of $E$. coli transketolase by aqueous co-solvents
}

\author{
Phattaraporn Morris ${ }^{1,2}$, Ribia García-Arrazola ${ }^{1}$, Leonardo Rios-Solis ${ }^{3,4}$ \& Paul A. Dalby ${ }^{1 凶}$
}

Transketolase (TK) has been previously engineered, using semi-rational directed evolution and substrate walking, to accept increasingly aliphatic, cyclic, and then aromatic substrates. This has ultimately led to the poor water solubility of new substrates, as a potential bottleneck to further exploitation of this enzyme in biocatalysis. Here we used a range of biophysical studies to characterise the response of both E. coli apo- and holo-TK activity and structure to a range of polar organic co-solvents: acetonitrile (AcCN), $n$-butanol ( $\mathrm{nBuOH}$ ), ethyl acetate (EtOAc), isopropanol (iPrOH), and tetrahydrofuran (THF). The mechanism of enzyme deactivation was found to be predominantly via solvent-induced local unfolding. Holo-TK is thermodynamically more stable than apo-TK and yet for four of the five co-solvents it retained less activity than apo-TK after exposure to organic solvents, indicating that solvent tolerance was not simply correlated to global conformational stability. The co-solvent concentrations required for complete enzyme inactivation was inversely proportional to co-solvent $\log (\mathrm{P})$, while the unfolding rate was directly proportional, indicating that the solvents interact with and partially unfold the enzyme through hydrophobic contacts. Small amounts of aggregate formed in some cases, but this was not sufficient to explain the enzyme inactivation. TK was found to be tolerant to $15 \%(\mathrm{v} / \mathrm{v}) \mathrm{iPrOH}, 10 \%(\mathrm{v} / \mathrm{v}) \mathrm{AcCN}$, or $6 \%(\mathrm{v} / \mathrm{v}) \mathrm{nBuOH}$ over $3 \mathrm{~h}$. This work indicates that future attempts to engineer the enzyme to better tolerate co-solvents should focus on increasing the stability of the protein to local unfolding, particularly in and around the cofactorbinding loops.

Biocatalysis has become increasingly powerful for the efficient synthesis of optically pure pharmaceuticals, agrochemicals, food ingredients, nutraceuticals, and fragrances ${ }^{1-8}$. A key challenge in biocatalysis is to overcome the poor solubility in aqueous media for many organic molecules of interest ${ }^{9,10}$. Eutectic solvents have emerged as an interesting alternative in this topic ${ }^{11,12}$. While biocatalysts are often limited in terms of their stability under industrial process conditions, directed evolution and rational enzyme engineering can potentially be used to address many of these issues, which include poor stability at extremes of $\mathrm{pH}$, temperature and under oxidative stress ${ }^{13-16}$.

Many syntheses involve organic substrates or products that are poorly soluble in water, or are sensitive to aqueous degradation, resulting in a need for enzymes that operate efficiently in organic media, aqueous-organic mixtures, or aqueous two-phase systems ${ }^{17,18}$. Many enzymes can function in both aqueous and near-anhydrous organic solvents ${ }^{19,20}$, and in some cases organic solvents are found to improve enzyme stability or even alter their enantioselectivity ${ }^{21-23}$. The impact of solvents on protein structure and dynamics ${ }^{24}$ have been characterised extensively in near-anhydrous systems where the enzymes are typically freeze-dried or chemically cross-linked prior to addition to organic solvents. However, most enzymes are rapidly inactivated even at low concentrations of organic co-solvents, and yet the mechanisms of activity loss remain unclear ${ }^{25,26}$. Activity loss is typically solvent concentration dependent, but varies with organic solvent, potentially depending on solvent hydrophobicity ${ }^{27,28}$.

Enzymes typically have lower reaction rates in organic media relative to those in aqueous solutions, and yet they are often found to retain their overall native structure ${ }^{29}$. However, direct structural investigations of enzymes

\footnotetext{
${ }^{1}$ Department of Biochemical Engineering, University College London, Bernard Katz Building, Gower Street, London WC1E 6BT, UK. ${ }^{2}$ Chemical Metrology and Biometry Department, National Institute of Metrology, 3/4-5 Moo 3, Klong 5, Klong Luang 12120, Pathumthani, Thailand. I'Institute for Bioengineering, School of Engineering, University of Edinburgh, Edinburgh EH9 3JL, UK. ${ }^{4}$ Centre for Synthetic and Systems Biology (SynthSys), University of Edinburgh, King's Buildings, Edinburgh EH9 3JL, UK. ${ }^{\circledR}$ email: p.dalby@ucl.ac.uk
} 


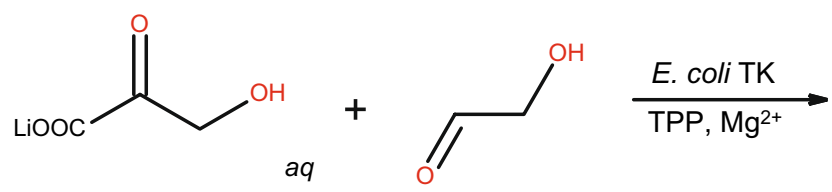

Lythium

$\beta$-hydroxypyruvate hydrate

$(\beta-\mathrm{HPA})$
Glycolaldehyde

(GlyAl)

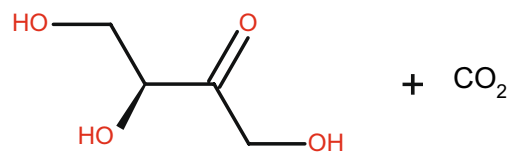

L-erythrulose

(L-Ery)

Figure 1. Reaction of transketolase.

that are either suspended or solubilized into organic media are difficult, and so in the past, activity assays have been relied upon to give an indirect probe of protein structure and function. As a result, the mechanisms leading to partial inactivation of enzymes in organic solvents are still not clear, or generalizable to a wide range of enzymes such that they elucidate the relative roles of protein-solvent interactions, surface or active-site dehydration, structural denaturation, partial unfolding, subunit or cofactor dissociation, and enzyme aggregation ${ }^{30-32}$.

To take advantage of the benefits of organic solvents in biocatalysis, many efforts have been made to enhance enzyme activity and stability in aqueous-organic mixtures, particularly using enzyme immobilization ${ }^{33-35}$, directed evolution ${ }^{36,37}$ and recently viral nanoparticle-encapsulated enzymes among other strategies ${ }^{38}$. These studies have provided useful insights into the impact of organic solvents on enzyme structure and activity. However, novel rational or computational design of organic solvent tolerant enzymes, and their directed evolution, could be significantly improved if the mechanisms by which organic solvents cause enzyme inactivation were better understood.

Escherichia coli transketolase (TK) (EC 2.2.1.1) is a homodimeric enzyme in which each $78 \mathrm{kDa}$ subunit comprises three domains, and the apo-TK homodimer binds two $\mathrm{Ca}^{2+}$ or $\mathrm{Mg}^{2+}$ ions, and two thiamine diphosphate (TPP) cofactors to form the active holo-TK enzyme ${ }^{39,40}$. It catalyses the stereoselective transfer of a two-carbon ketol group to an aldose sugar producing a new asymmetric carbon-carbon bond, at two steps within the reductive pentose phosphate pathway ${ }^{41}$. The reaction is rendered irreversible in vitro by the release of carbon dioxide, when using $\beta$-hydroxypyruvate as the ketol donor (Fig. 1). These features make the enzyme attractive for the biocatalytic synthesis of complex carbohydrates and their analogues ${ }^{42-44}$, as applied in the industrial synthesis of xylulose-5-phosphate ${ }^{45,46}$.

The synthetic potential of $E$. coli TK has already been significantly improved by successive rounds of directed evolution with smart libraries ${ }^{47,48}$, to enhance activity towards polar ${ }^{49,50}$, and increasingly aliphatic ${ }^{51-53}$, and heterocyclic substrates ${ }^{51,54}$, to enhance and reverse enantioselectivity ${ }^{55}$. Similar engineering of substrate specificity has been achieved in TK from other organisms ${ }^{56,57}$. De novo pathways containing improved TK variants have also been designed for the synthesis of optically pure high-value amino-diols ${ }^{58,59}$. Most recently the "substrate-walk" by directed evolution was continued to obtain variant " $3 \mathrm{M}$ " which introduced new activity towards substituted benzaldehyde substrates ${ }^{60}$, and then evolved further for simultaneous acceptance of pyruvate in the reaction with 3-formylbenzoic acid (3-FBA) ${ }^{61}$. However, many new benzaldehydes were too insoluble to test their activity, which has increased the need to explore the use of TK variants in the presence of organic co-solvents.

While we have previously characterised the activity, thermostability and aggregation of transketolase at a wide range of $\mathrm{pH}$, temperature, and chemical denaturant concentrations ${ }^{62,63}$, its stability in a range of organic co-solvents has not been previously determined. TK unfolds irreversibly with urea, heat, or at low $\mathrm{pH}$, and then aggregates, except in urea. Folded yet inactive states form during early urea-unfolding, and at high $\mathrm{pH}$, in which the cofactors remain bound. The enzyme then partially unfolds at higher urea prior to dissociation of the monomers.

Several differences in the protein conformation of the holo and apo TK have been previously observed, for example the secondary and tertiary structure of holo-TK remained constant from $\mathrm{pH} 5$ to 11 , whereas the apo-TK secondary structure content increased with $\mathrm{pH}^{62}$. The effects of varying the $\mathrm{Mg}^{2+}$ and TPP cofactor concentrations on TK activity have been well characterised, showing inactivity in apo-TK and the concentrations required to effectively reach maximum activity in holo- $\mathrm{TK}^{64}$. Recently, a mutation to proline in one of the two TK cofactor-binding loops was found to stabilise TK against aggregation at elevated temperatures ${ }^{14}$. Further engineering of these flexible loops led to improved thermostability of the wild-type $\mathrm{TK}^{48}$, while their inclusion into variant $3 \mathrm{M}$, along with two stabilising mutations at residues that were dynamically coupled to the cofactor binding loops, resulted in variants $5 \mathrm{M}$ and $7 \mathrm{M}$ which had improved stability and activity towards the aromatic aldehydes ${ }^{65}$. Thus, one or more of several potential mechanisms could influence TK stability and activity in the presence of organic co-solvents, including: (i) global unfolding, (ii) aggregation; (iii) destabilisation of local structure or domains; (iv) cofactor dissociation; and v modulating the accessibility of water molecules or substrates into the active site.

Here we have characterised the impact of different co-solvents used in the pharmaceutical industry, including acetonitrile $(\mathrm{AcCN}), n$-butanol $(\mathrm{nBuOH})$, ethyl acetate (EtOAc), isopropanol (iPrOH), and tetrahydrofuran (THF), on both apo-TK and holo-TK activity and conformation, and correlated this to the physico-chemical properties of the solvents. We also determined the extent to which global and local protein unfolding, and aggregation play a role in solvent-induced enzyme inactivation. This work has provided useful insights that will guide the future engineering of TK and other similarly complex enzymes. 


\section{Results}

Transketolase activity in organic co-solvents. Protein engineering of the cofactor-binding loops in TK was previously shown to improve the stability of TK to thermal aggregation ${ }^{14,48,65}$. They are also known to become more structured upon formation of holo- $\mathrm{TK}^{40}$, leading to increased thermostability compared to apo-TK ${ }^{62,63,66}$. Therefore, to understand the effect of polar organic co-solvents upon TK stability, including any potential role of the cofactor-binding loops, both apo-TK and holo-TK were incubated with five selected polar co-solvents at a range of concentrations from 0 to $30 \%(\mathrm{v} / \mathrm{v})$. In the first case, apo-TK was incubated with the organic solvents for $3 \mathrm{~h}$ and then incubated with the cofactor to form the holo-TK before diluting and adding the substrates. In the second case, to test holo-TK, the apo-TK was first incubated with cofactors to form the holo$\mathrm{TK}$, and then incubated with organic solvents for $3 \mathrm{~h}$ before diluting and adding the substrates. In both cases, the solvent incubations were shaken at $1000 \mathrm{rpm}$ to ensure that the least miscible solvents, ethyl acetate (EtOAc), and $n$-butanol $(\mathrm{nBuOH})$ were either fully dissolved or formed into emulsions at the higher concentrations (biphasic systems were only formed for EtOAc and $\mathrm{nBuOH}$ at concentrations of 8.3 and $7.3 \% \mathrm{v} / \mathrm{v}$ respectively).

The results shown in Fig. 2 compare the effect of increasing the final solvent concentrations, upon the activity retained after $3 \mathrm{~h}$, for apo-TK and holo-TK. As a control, we also measured the impact of the co-solvents on the residual activity of apo-TK in the absence of any added cofactors (Fig. 3) which is due to binding of endogenous cofactors during protein expression. This confirmed that the residual enzyme activity was 286 -fold less than for the co-solvent-free holo-TK, as observed previously in lysates ${ }^{64}$. The activity from the residual holo-TK within the apo-TK preparation, also had a similar dependence on the co-solvent concentrations as the holo-TK preparations.

In nearly all cases, the increased concentration of co-solvents eventually reduced the remaining activity to zero (Fig. 2). Apo-TK was more stable than holo-TK to three of the solvents tested, but less stable than holo-TK in $\mathrm{nBuOH}$, and essentially of the same stability as holo-TK in iso-propanol (iPrOH). For example, acetonitrile $(\mathrm{AcCN})$ half-inactivated apo-TK and holo-TK at 20\% (v/v) and $12 \%(\mathrm{v} / \mathrm{v})$, respectively. Similarly, EtOAc halfinactivated holo-TK at approximately $3 \%(\mathrm{v} / \mathrm{v})$, and at $6 \%(\mathrm{v} / \mathrm{v})$ EtOAc for apo-TK. Nevertheless, apo-TK retained $18 \%$ residual activity at 30\% (v/v) EtOAc, whereas holo-TK was already completely inactivated by $15 \%(\mathrm{v} / \mathrm{v})$. The sharp decrease in activity up to $10 \%$ EtOAc and the apparent retention of activity above it for both apo and holo-TK potentially resulted from having reached the $8.3 \%(\mathrm{v} / \mathrm{v})$ solubility of EtOAc in water ${ }^{67}$. Increasing the concentration at above $8.3 \%(\mathrm{v} / \mathrm{v})$ EtOAc, formed emulsions which affected the deactivation profile of apo-TK and holo-TK. Holo-TK was completely inactivated by $15 \%(\mathrm{v} / \mathrm{v})$, but not for apo-TK, even at $30 \%(\mathrm{v} / \mathrm{v})$.

In $\mathrm{iPrOH}$, both apo-TK and holo-TK behaved similarly, with a gradual drop-in activity until there was no activity in either case at $25 \%(\mathrm{v} / \mathrm{v}) \mathrm{iPrOH}$. Tetrahydrofuran (THF) was the most effective at deactivation, with holo-TK completely inactivated at just $2 \%(\mathrm{v} / \mathrm{v})$ THF and apo-TK at $4 \%(\mathrm{v} / \mathrm{v})$ THF. By contrast, apo-TK was less stable to $\mathrm{nBuOH}$ than holo-TK with concentrations of $2 \%(\mathrm{v} / \mathrm{v})$ and $7 \%(\mathrm{v} / \mathrm{v})$ respectively giving rise to $50 \%$ activity. For both apo-TK and holo- $\mathrm{TK}$ in $\mathrm{nBuOH}$ the residual activity tended to zero after reaching the $7.3 \%(\mathrm{v} / \mathrm{v})$ solubility limit for $\mathrm{nBuOH}$.

The generally lower tolerance of holo-TK to co-solvents compared to apo-TK is counterintuitive given that holo-TK is thermodynamically more stable than apo-TK. The dependence on solvent concentration is also clearly not simple. For example, $\mathrm{AcCN}, \mathrm{nBuOH}$ and $\mathrm{iPrOH}$ displayed an initial lag at low solvent concentrations, where the activity decreased only slightly, before reaching a critical concentration at which deactivation occurred more abruptly. Such sigmoidal profiles can indicate a cooperative transition for structural unfolding or even the dissociation of protein dimers into monomers. By contrast, THF and EtOAc titrated out the activity rapidly with increasing concentration of co-solvent, suggesting either an isotherm for solvent binding to the protein, or that any cooperative structural transition was already well underway at the lowest concentration of co-solvent tested.

As apo-TK is already known to be less thermodynamically stable than holo-TK, and yet was found typically to be more co-solvent tolerant, TK inactivation by co-solvent did not appear to relate simply to the global conformational stability (or global denaturation) of the protein. Further biophysical characterisations were undertaken to elucidate whether inactivation was due to global protein denaturation, local protein unfolding, protein aggregation, or some other effect on the protein structure that is not directly detected, such as activesite binding. Before that we determined any relationships between the properties of the co-solvents and their potency for enzyme inactivation.

Correlation of TK activity to calculated organic solvent properties. Although all the organic cosolvents in these experiments were polar, they showed considerable variability in their impact on retained TK activity, including their critical concentrations for inactivation, the sharpness of their deactivation curves, and also in their relative impacts upon apo-TK and holo-TK. The effectiveness of a polar solvent for inactivation of proteins might be expected to depend upon the polarity or hydrophobicity of the solvent, and also their ability to form hydrogen bonds in place of water.

The polar co-solvents can be categorized as aprotic (AcCN, EtOAc and THF), or protic ( $\mathrm{nBuOH}$ and $\mathrm{iPrOH})$. This simple categorization had no obvious correlation to the concentrations of co-solvents required for complete enzyme inactivation. The characteristics of each co-solvent used in terms of various theoretically calculated and experimentally determined physicochemical properties, is shown in Table 1 , along with the Pearson's $\mathrm{R}^{2}$ values for linear correlations between each co-solvent property, and the molar solvent concentrations required for complete inactivation of holo-TK. $\log (\mathrm{P})$ gave the best correlation for both apo-TK $\left(\mathrm{R}^{2}=0.87\right)$ and holo-TK $\left(\mathrm{R}^{2}=0.57\right)$ (Fig. 4). Other solvent properties correlated much less with the molar holo-TK inactivation concentration, such as the molecular weight $\left(R^{2}=0.4\right)$, molecular volume $\left(R^{2}=0.4\right)$, topological polar surface area $\left(R^{2}=0.3\right)$, number of potential hydrogen bonds $\left(\mathrm{R}^{2}=0.1\right)$, dipole moment $\left(\mathrm{R}^{2}=0.2\right)$, and the dielectric constant of the co-solvent $\left(R^{2}=0.4\right)$. Although the $\log (P)$ correlation was poor, it showed the highest $R^{2}$ which was consistent with previous observations that correlated hydrophobicity, and not the dielectric constant, to loss of enzyme activity and 


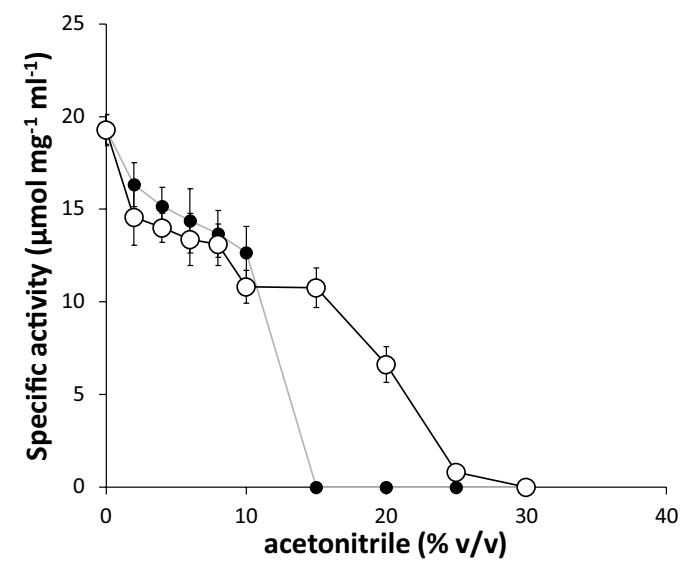

(a)

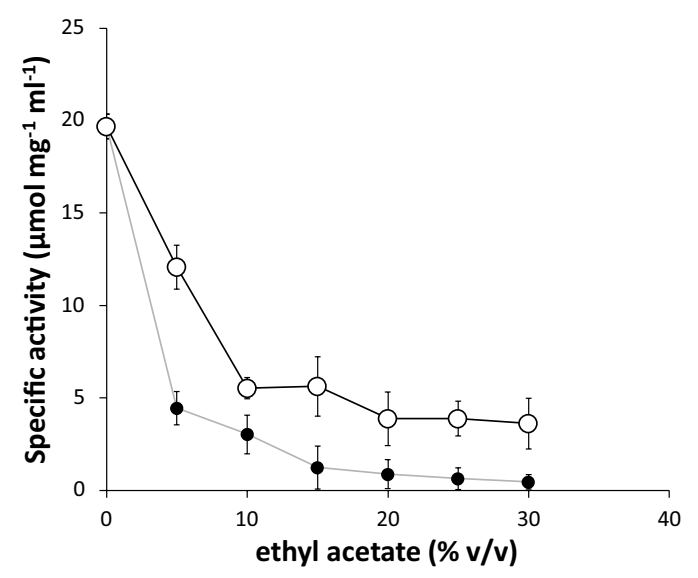

(c)

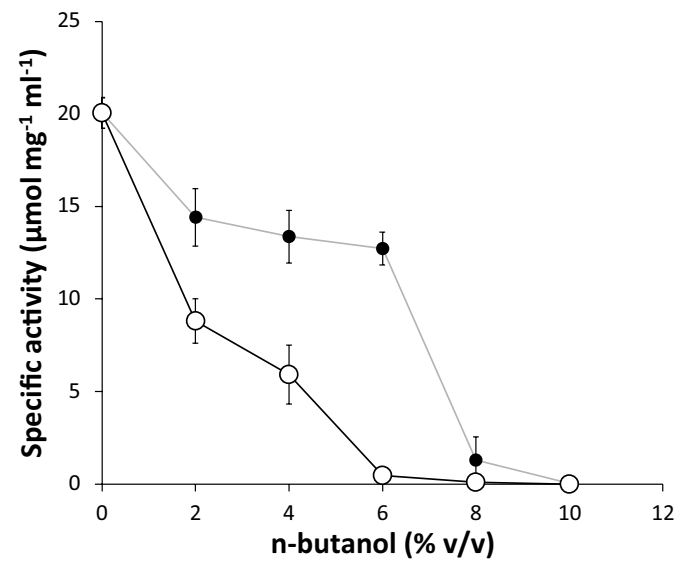

(b)

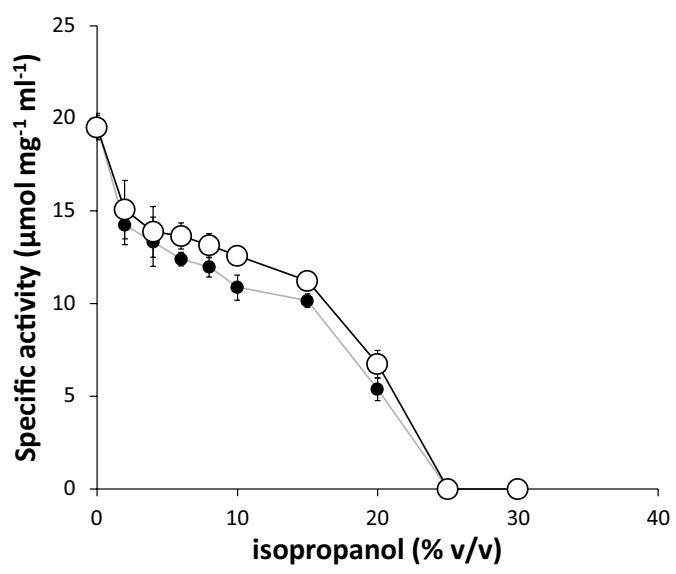

(d)

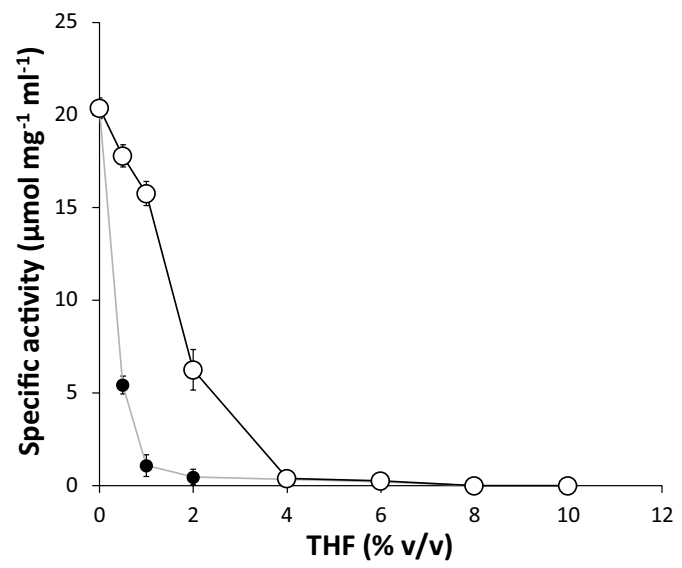

(e)

Figure 2. Retention of transketolase catalytic activity after pre-incubation with increasing concentrations of organic solvents. (open circle) Apo-TK and (filled circle) holo-TK were compared for their stability to incubation with (a) acetonitrile (b) n-butanol (c) ethyl acetate (d) isopropanol (e) THF, in $50 \mathrm{mM}$ Tris- $\mathrm{HCl}, \mathrm{pH}$ 7.0 (plus $4.8 \mathrm{mM}$ TPP, $18 \mathrm{mM} \mathrm{MgCl}$ for holo-TK), for $3 \mathrm{~h}$ at $25^{\circ} \mathrm{C}$ and $1000 \mathrm{rpm}$ shaking. Enzyme activity was measured after a 20-fold dilution of the solvents, at $50 \mathrm{mM} \mathrm{HPA}$ and $50 \mathrm{mM} \mathrm{GA}$ in $2.4 \mathrm{mM} \mathrm{TPP}, 9 \mathrm{mM} \mathrm{MgCl}$, $50 \mathrm{mM}$ Tris-HCl, $\mathrm{pH}$ 7.0. 


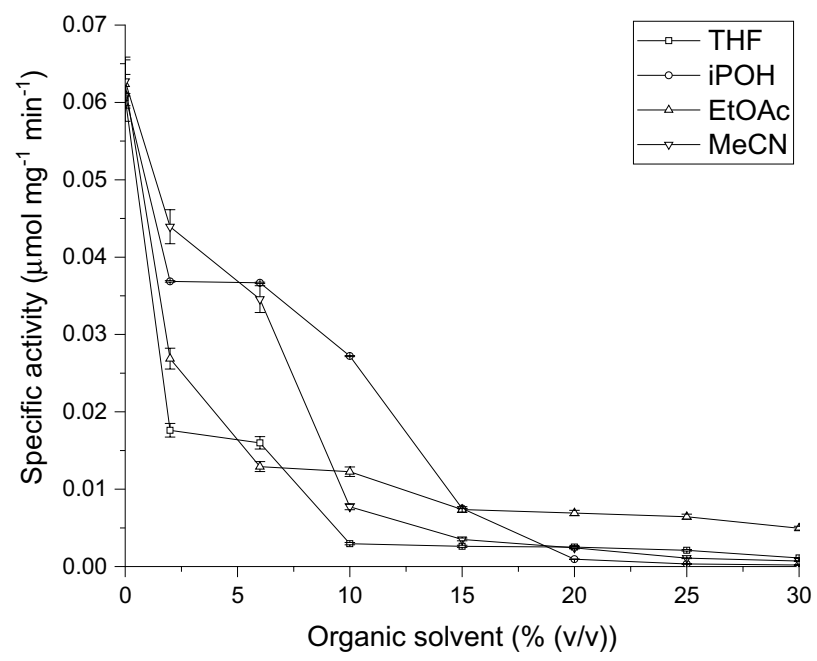

Figure 3. Retention of transketolase catalytic activity in cofactor-free systems with increasing concentrations of organic solvents. Apo-TK was compared for its stability to incubation with (open square)) THF, (open circle) isopropanol, (open triangle) ethyl acetate and (inverted open triangle) acetonitrile, in $50 \mathrm{mM}$ Tris- $\mathrm{HCl}, \mathrm{pH} 7.0$ (plus $4.8 \mathrm{mM}$ TPP, $18 \mathrm{mM} \mathrm{MgCl}_{2}$ for holo-TK), for $3 \mathrm{~h}$ at $25^{\circ} \mathrm{C}$ and $1000 \mathrm{rpm}$ shaking. Enzyme activity was measured after a 20-fold dilution of the solvents, at $50 \mathrm{mM} \mathrm{HPA}$ and $50 \mathrm{mM} \mathrm{GA}$ in $2.4 \mathrm{mM}$ TPP, $9 \mathrm{mM} \mathrm{MgCl}_{2}$, $50 \mathrm{mM}$ Tris- $\mathrm{HCl}, \mathrm{pH}$ 7.0. Error bars represent one standard deviation about the mean $(\mathrm{n}=3)$.

\begin{tabular}{|l|l|l|l|r|l|l|l|l|l|}
\hline Solvent & {$[\mathbf{S 0}]^{\mathbf{a}}(\% \mathbf{( v / v )})$} & {$[\mathbf{S 0}]^{\mathbf{a}}(\mathbf{M})$} & $\mathbf{T P S A}^{\mathbf{b}}\left(\AA^{2}\right)$ & \multicolumn{1}{|c|}{$\log ^{\mathbf{c}}$} & $\mathbf{V o l}^{\mathbf{b}}\left(\AA^{3}\right)$ & $\mathbf{M W}^{\mathbf{b}}(\mathbf{D a})$ & $\mathbf{H B}^{\mathbf{d}}$ & Dielectric constant $^{\mathbf{e}}$ & $\mathbf{D i p o l e}^{\mathbf{e}}(\mathbf{D})$ \\
\hline THF & 2 & 0.25 & 9.23 & 0.46 & 78 & 72 & 2 & 7.58 & 1.75 \\
\hline EtOAc & 15 & 1.5 & 26.3 & 0.73 & 90.5 & 88 & 4 & 6.02 & 1.88 \\
\hline AcCN & 15 & 2.9 & 23.8 & -0.34 & 46.1 & 41 & 1 & 37.5 & 3.44 \\
\hline iPrOH & 25 & 3.3 & 20.2 & 0.05 & 70.6 & 60 & 2 & 19.9 & 1.66 \\
\hline $\mathrm{nBuOH}$ & 8 & 0.9 & 20.2 & 0.84 & 87.6 & 74 & 2 & 17.5 & 1.75 \\
\hline $\mathrm{R}^{2 f}$ & & 0.3 & 0.57 & 0.4 & 0.4 & 0.1 & 0.4 & 0.2 \\
\hline
\end{tabular}

Table 1. Correlation of holo-TK inactivation to physicochemical properties of the polar organic solvents. ${ }^{a}$ Concentration of solvent required for complete $\left[\mathrm{S}_{0}\right]$ inactivation of holo-TK. ${ }^{\mathrm{b}}$ Calculated using the Molinsky online software tool (http://www.molinspiration.com). ${ }^{c}$ Experimental values from Sangster ${ }^{77}$. ${ }^{\mathrm{d}}$ Number of potential hydrogen bond acceptor and donor sites. ${ }^{e}$ Obtained from the Louisiana State University Macromolecular Studies Group Server (http://macro.lsu.edu/). ${ }^{\mathrm{f}} \mathrm{R}^{2}$ values are for linear Pearson correlations to $\left[\mathrm{S}_{0}\right]$ in Molar.

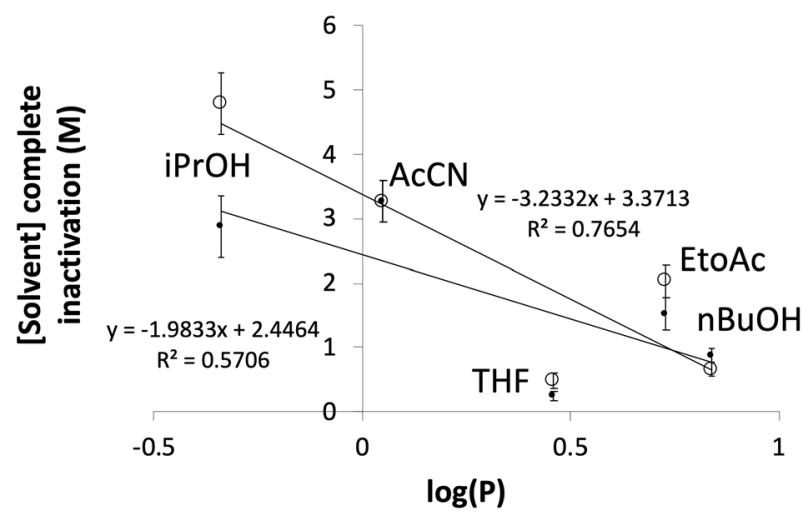

Figure 4. Correlations of solvent $\log (\mathrm{P})$ with their $\mathrm{TK}$ inactivation potency. $\log (\mathrm{P})$ correlates well with the molar concentration required to inactivate either (open circle) holo-TK or (filled circle) apo-TK. Error bars represent one standard deviation about the mean $(n=3)$. 


\begin{tabular}{|c|c|c|c|c|c|c|c|c|c|}
\hline \multirow[b]{2}{*}{ Solvent } & \multirow[b]{2}{*}[\mathrm{S}]{$^{\mathrm{a}}(\%(\mathrm{v} / \mathrm{v}))$} & \multicolumn{2}{|c|}{$\begin{array}{l}\text { Activity at } \\
3 \mathbf{h}(\%)\end{array}$} & \multicolumn{2}{|c|}{$\begin{array}{l}\mathrm{CD}^{\mathrm{b}} \% \\
\text { native holo } \\
\text { TK }( \pm 2 \%)\end{array}$} & \multicolumn{2}{|c|}{$\begin{array}{l}\text { CD initial } \\
\text { rate } \\
\text { unfolding } \\
\left.\mathbf{h}^{-1}\right)\end{array}$} & \multirow{2}{*}{\begin{tabular}{|l} 
FLI transition ${ }^{\mathrm{d}}(\%(\mathrm{v} / \mathrm{v}))$ \\
Holo
\end{tabular}} & \multirow{2}{*}{\begin{tabular}{|l|} 
DLS \\
Holo
\end{tabular}} \\
\hline & & \begin{tabular}{|l|} 
Holo \\
\end{tabular} & Apo & $\mathbf{O h}$ & $3 \mathrm{~h}$ & Holo & Apo & & \\
\hline None & 0 & 100 & 100 & 100 & 101 & 0 & 0 & $\mathrm{n} / \mathrm{a}$ & $7 \mathrm{~nm}$ \\
\hline \begin{tabular}{|l|} 
THF \\
\end{tabular} & 2 & 0 & 32 & 78 & 74 & 1.7 & 1.7 & None & $9 \mathrm{~nm}$ \\
\hline EtOAc & 10 & 15 & 31 & 99 & 98 & 1.2 & 1.4 & None & $8 \mathrm{~nm}$ \\
\hline AcCN & 20 & 0 & 35 & 90 & $54^{\mathrm{f}}$ & 16.2 & 1.1 & $>15 \%$ & $>1000 \mathrm{~nm}$ \\
\hline iPrOH & 20 & 30 & 35 & 100 & 95 & 1.4 & 1.0 & $>22 \%$ & $15 \mathrm{~nm}$ \\
\hline $\mathrm{nBuOH}$ & 8 & 10 & 0 & 98 & 98 & 0.8 & 2.1 & $7-8 \%$ & $>1000 \mathrm{~nm}$ \\
\hline
\end{tabular}

Table 2. Effects of polar organic co-solvents on TK structure and activity after $3 \mathrm{~h}$ at $25{ }^{\circ} \mathrm{C}$. ${ }^{\mathrm{a}}$ Concentration of solvent added. ${ }^{\mathrm{b}} \mathrm{CD} \%$ Native based on signal at $222 \mathrm{~nm}$, except EtOAc which is based on signal at $223 \mathrm{~nm}$ to avoid a high dynode voltage at $<222 \mathrm{~nm}$. ' Initial rate of unfolding was determined by converting mean residue ellipticity into \% loss of native structure, and by subtracting the baseline rate determined in the absence of solvent. ${ }^{\mathrm{d}}$ Fluorescence intensity. ${ }^{\mathrm{e}}$ Time dependence of fluorescence intensity (approximate time taken to reach equilibrium). ${ }^{\mathrm{f}}$ Aggregated after $4.5 \mathrm{~h}$.

stability ${ }^{25,68,69}$. However, various mechanisms have been used to explain such previous correlations, and so we sought to further characterise the solvent-induced inactivation of TK, as summarised in Table 2 and described below.

Secondary structure of apo-TK and holo-TK in polar co-solvents. To determine the impact of cosolvents on the secondary structure content of TK, and also whether the enzyme was unfolding globally or partially, or aggregating, far-UV circular dichroism (CD) spectra were obtained at approx. 30-45 min intervals for between 3 and $22 \mathrm{~h}$, for both apo-TK and holo-TK, using each volume fraction of solvent that resulted in $\approx 70 \%$ inactivation of the apo-TK enzyme (specific activity of $6 \mu \mathrm{mol} \mathrm{mg}^{-1} \mathrm{~min}^{-1}$ ), except for $\mathrm{nBuOH}$ which was increased to ensure holo-TK was also inactivated.

The time dependencies of the mean residue ellipticity at $222 \mathrm{~nm}$ for apo-TK and holo-TK in each co-solvent, and also without co-solvent, are shown in Fig. 5A, and the initial rates of secondary structure loss are shown in Table 2. The far-UV CD spectra of holo-TK, after incubation with co-solvents for $3 \mathrm{~h}$, are also shown in Fig. 5B. It can be seen in Fig. 5A that the control samples of apo-TK and holo-TK with no added co-solvent, each showed no loss of secondary structure content over the course of at least $4 \mathrm{~h}$. By contrast, relative to the control samples, the co-solvents each induced small initial losses of secondary structure at rates of between 1.0 and $2.1 \% \mathrm{~h}^{-1}$ for apo-TK, and between 0.8 and $1.7 \% \mathrm{~h}^{-1}$ for holo-TK, except for AcCN with holo-TK which led to a more rapid loss of $16 \% \mathrm{~h}^{-1}$. Apo-TK and holo-TK had similar rates in any given solvent, except for in AcCN where holoTK lost secondary structure at a rate that was 15 -fold faster than for apo-TK, and conversely for $\mathrm{nBuOH}$ where apo-TK had a 2.7-fold higher rate than holo-TK. AcCN with holo-TK was the only sample for which aggregates were detected by CD as indicated after $4.5 \mathrm{~h}$ of secondary structure loss, by a sudden and simultaneous increase in the dynode voltage and mean residue ellipticity.

It can be seen from Fig. 5A that all samples, except for THF, began with the same initial secondary structure content, with a mean residue ellipticity at $222 \mathrm{~nm}$ of $-13,500 \pm 500 \mathrm{deg} \mathrm{cm}^{2} \mathrm{dmol}^{-1}$. THF by contrast appeared to begin with only $78 \%$ of the native structure $\left(-10,590 \mathrm{deg} \mathrm{cm}{ }^{2} \mathrm{dmol}^{-1}\right)$, yet this only decreased to $74 \%$ after $3 \mathrm{~h}$. The far-UV spectrum taken after $3 \mathrm{~h}$ in THF (Fig. 5B), and at all earlier time-points (not shown), indicated that the smaller ellipticity at $222 \mathrm{~nm}$ was due to distortion away from the spectrum expected from a predominantly $\alpha$-helical protein. This was due to absorbance flattening by THF, that gave a correspondingly increased dynode voltage at $224 \mathrm{~nm}$ and below (not shown), to above that acceptable for the instrument, rather than resulting from any actual loss of native structure or conformational change immediately after the addition of THF. EtOAc was similarly affected by a high dynode voltage at below $222 \mathrm{~nm}$ leading to considerable signal scattering at below $215 \mathrm{~nm}$ at all time-points.

From Fig. 6A,B it can be seen that the initial rates of secondary structure loss determined by CD were found to correlate well ( $\mathrm{R}^{2}$ of 0.91 for apo-TK, 0.71 for holo-TK, and 0.73 combined) to the activity retained after $3 \mathrm{~h}$ of incubation with the co-solvents, and also to the $\log (\mathrm{P})$ of the co-solvents ( $\mathrm{R}^{2}$ of 0.94 for apo-TK), when excluding the case of AcCN for holo-TK. This indicated that the inactivation of the enzyme by co-solvent for both apo-TK and holo-TK was linked to the slow loss of secondary structure observed in most samples. Furthermore, as the secondary structure loss of only $0.8-2.1 \% \mathrm{~h}^{-1}$ led to $70-100 \%$ inactivation in apo-TK and holo-TK, then the far-UV CD signal change was most likely due to local destabilisation and unfolding, including at one or more functionally critical elements of structure within the entire protein population, rather than global unfolding of only $2.1 \%$ of the protein population.

For AcCN with holo-TK, the significantly higher rate of unfolding, led to $54 \%$ native structure after $3 \mathrm{~h}$, and indicated that AcCN had induced global unfolding, from which aggregation then occurred after $4.5 \mathrm{~h}$. HoloTK was completely inactive after $3 \mathrm{~h}$, indicating that global unfolding could only account for up to $54 \%$ of the inactivation mechanism, and therefore that the local unfolding observed with apo-TK in AcCN, had additionally inactivated holo-TK. 
Particle size distributions from dynamic light scattering. Dynamic light scattering (DLS) was used to measure particle size distributions of holo-TK in the presence of the co-solvents (see supplementary Fig. S1). Holo-TK in the absence of organic co-solvent gave a particle size of 7-8 nm as expected theoretically from the native homodimer structure ${ }^{70}$. At $20 \%(\mathrm{v} / \mathrm{v}) \mathrm{AcCN}$ and $8 \%(\mathrm{v} / \mathrm{v}) \mathrm{nBuOH}$, holo-TK at $0.1 \mathrm{mg} \mathrm{m}^{-1}$ contained DLS-detectable aggregates of $1000-4000 \mathrm{~nm}$ within $1 \mathrm{~h}$ of incubation. At $20 \%(\mathrm{v} / \mathrm{v}) \mathrm{iPrOH}$ a very small aggregate peak at $400 \mathrm{~nm}$ was observed within $1 \mathrm{~h}$, but more significantly, the monomer peak had shifted to approximately $15 \mathrm{~nm}$ indicating either the formation of a soluble oligomer, a shifted monomer peak due to viscosity effects, the formation of a solvent boundary layer, or otherwise significant protein unfolding. In $10 \%(\mathrm{v} / \mathrm{v})$ EtOAc, only the native-like peak was detected at $8 \mathrm{~nm}$ indicating the retention of the homodimer, and no aggregation. For $2 \%$ (v/v) THF, the native-like peak increased slightly within $1 \mathrm{~h}$ to $9 \mathrm{~nm}$, indicating a homodimer with the peakshift due to altered solvent viscosity, although not inconsistent with partial local unfolding, or the formation of a significant solvent boundary layer associated with the homodimer. No aggregates were detected with THF.

It should be noted that by DLS, the \% volume is proportional to the cube of the particle diameter, and hence even very small amounts of aggregates can suppress the detection of the native monomer peak. Therefore, it is very possible that the monomer, or even the $15 \mathrm{~nm}$ state observed for $\mathrm{iPrOH}$, was present also for AcCN or $\mathrm{nBuOH}$, but suppressed by the presence of larger $(>1000 \mathrm{~nm})$ aggregates. In iPrOH, the smaller $(400 \mathrm{~nm})$ aggregate was clearly a very low-populated aggregate which allowed the $15 \mathrm{~nm}$ state to be observed. Overall, these results are consistent with the emergence of low levels of aggregates in $\mathrm{nBuOH}$ and iPrOH, more significant aggregation in AcCN as detected also by $\mathrm{CD}$, and no aggregation observed by any method in EtOAc or THF. Therefore, aggregation was not well correlated to enzyme inactivation, as all solvents led to at least $70 \%$ inactivation of holo-TK. Only the significant levels of aggregate observed by CD could potentially contribute to enzyme inactivation for holo-TK, but this only occurred after $4.5 \mathrm{~h}$ of incubation, and for one solvent only (AcCN).

Fluorescence spectroscopy of apo-TK and holo-TK in polar co-solvents. Fluorescence tryptophan spectroscopy has been previously successfully applied to provide tertiary structural information for $\mathrm{TK}^{62,63,66,71}$. For E. coli TK, there are 11 tryptophan residues per monomer which dominate the intrinsic fluorescence signal. These are distributed across the entire structure, with three fully buried and eight partially solvent exposed within each monomer, three located at or close to the dimer interface, and one of those being within one of the cofactor-binding loops. Thus, the intrinsic fluorescence of $E$. coli TK is responsive to global and local unfolding, dimer dissociation and aggregation, and can lead to both an increase or decrease in intrinsic fluorescence intensity, as observed previously where urea denaturation gave an initial increase followed by a decrease at higher urea concentrations ${ }^{63}$. By contrast, thermal unfolding results in immediate aggregate formation which gives an increase in the fluorescence intensity of TK as a single cooperative transition due to a net burial of the partially exposed tryptophan residues.

Figure 7 shows the time-dependence of intrinsic fluorescence intensities, for holo-TK in 5-30\% (v/v) cosolvent. EtOAc and THF both resulted in steady decreases in fluorescence over time, for all concentrations tested. EtOAc at 10\% (v/v) led to a 7\% decrease in fluorescence, and THF at 5\% (v/v) led to a 9\% decrease, each after $3 \mathrm{~h}$ of incubation. These results are consistent with the local unfolding without aggregation as observed by $\mathrm{CD}$ above. By contrast, the fluorescence intensities for $\mathrm{AcCN}, \mathrm{nBuOH}$ and $\mathrm{iPrOH}$, resulted in lag-phases followed by rapid increases in fluorescence. The rapid increase occurred progressively earlier with increasing co-solvent concentration, and for AcCN at least the lag phase disappeared at the highest concentrations. This lag-phase behaviour is typical of aggregation kinetics ${ }^{72}$, and the fluorescence increases occurred in the same samples for which aggregation was observed by DLS. For $20 \%(\mathrm{v} / \mathrm{v}) \mathrm{AcCN}$, the fluorescence intensity increased over a timescale consistent with the global unfolding and aggregation observed by $\mathrm{CD}$. For $\mathrm{AcCN}, \mathrm{nBuOH}$ and $\mathrm{iPrOH}$, it remained possible that the fluorescence changes indicative of aggregation, were also convoluted with contributions from the local unfolding events observed by CD.

The effect of increasing co-solvent concentration on intrinsic fluorescence, as measured after 1,2 , and $3 \mathrm{~h}$ of incubation, is shown for apo-TK in Fig. 8 and holo-TK in Fig. 9. For apo-TK, the addition of co-solvents resulted in up to a $10 \%$ increase in the intrinsic fluorescence after $3 \mathrm{~h}$ in $\mathrm{AcCN}, \mathrm{nBuOH}, \mathrm{iPrOH}$ and EtOAc (Fig. 7), consistent with local rather than global unfolding. Increases were monotonic for $0-30 \%(\mathrm{v} / \mathrm{v}) \mathrm{AcCN}, 4-30 \%(\mathrm{v} / \mathrm{v})$ $\mathrm{nBuOH}, 10-30 \%(\mathrm{v} / \mathrm{v}) \mathrm{iPrOH}$, and 0-29\% (v/v) for EtOAc. Below 10\% (v/v) iPrOH there was no change, and at $30 \%(\mathrm{v} / \mathrm{v})$ EtOAc there was a small increase. For THF, the fluorescence intensity decreased exponentially, with most of the change completed over $0-10 \%(\mathrm{v} / \mathrm{v})$. The lack of obvious transitions for AcCN, EtOAc and THF, and yet clear transitions at $0-4 \%(\mathrm{v} / \mathrm{v}) \mathrm{nBuOH}$, and $10 \%(\mathrm{v} / \mathrm{v}) \mathrm{iPrOH}$, were consistent with the inactivation profiles for apo-TK in Fig. 3.

For holo-TK the addition of co-solvents resulted in similar profiles to those for apo-TK, in EtOAc and THF (Fig. 9). AcCN and iPrOH each gave no change initially and then increased sharply at above $15 \%(\mathrm{v} / \mathrm{v})$ and $22 \%$ (v/v) respectively. In $\mathrm{nBuOH}$, the fluorescence intensity showed a small increase that was monotonic overall, but with a small and sharp increase at $7-8 \%$. These three sharp transitions are larger than any transitions observed in apo-TK, which didn't aggregate, and they are consistent with the aggregation behaviour of holo-TK observed as time-dependent lag-phases in Fig. 7, and by DLS. Again, the lack of obvious transitions for EtOAc and THF, and yet clear transitions at 15\% (v/v) AcCN, 7-8\% (v/v) nBuOH, and 22\% (v/v) iPrOH, are consistent with the inactivation profiles for holo-TK in Fig. 3. However, the aggregate formation for holo-TK tended to occur at slightly higher solvent concentrations than the holo-TK inactivation, suggesting that it occurred after inactivation, and therefore that aggregates formed from an already inactive enzyme. This was consistent with the earlier observation by $\mathrm{CD}$ that inactivation was primarily due to a local unfolding event (or global unfolding in the case of AcCN with holo-TK), and that in some cases for holo-TK this also led to aggregation. 
A.
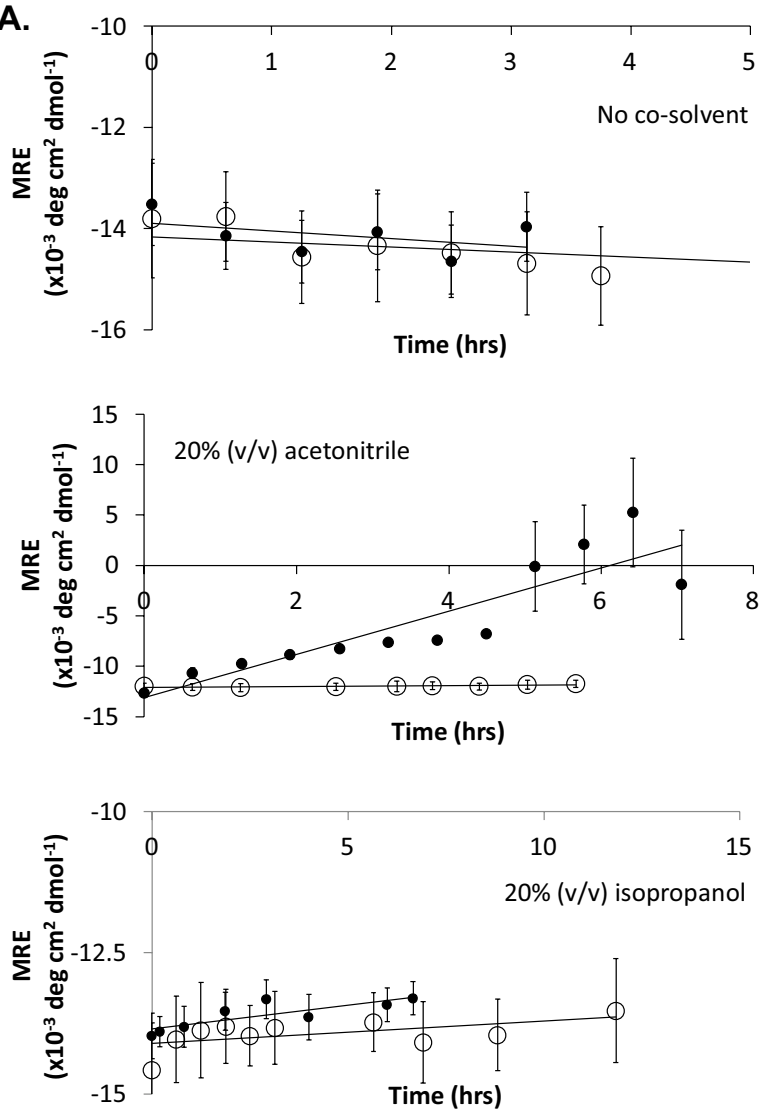
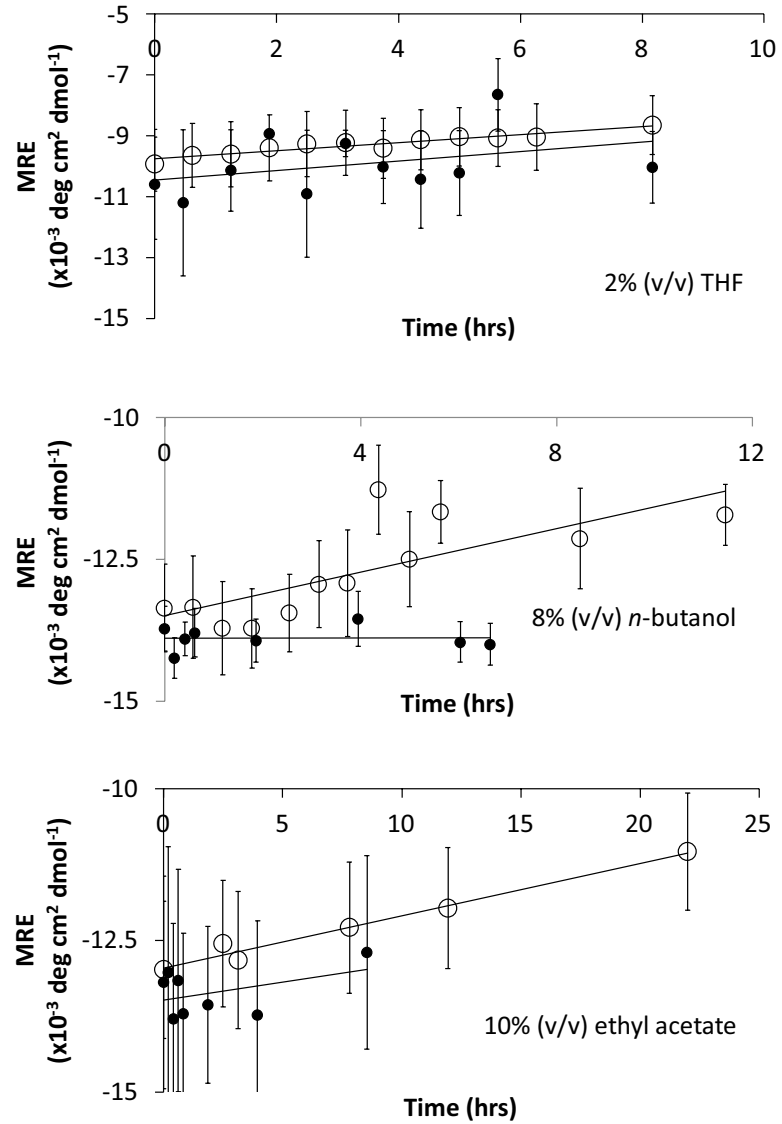
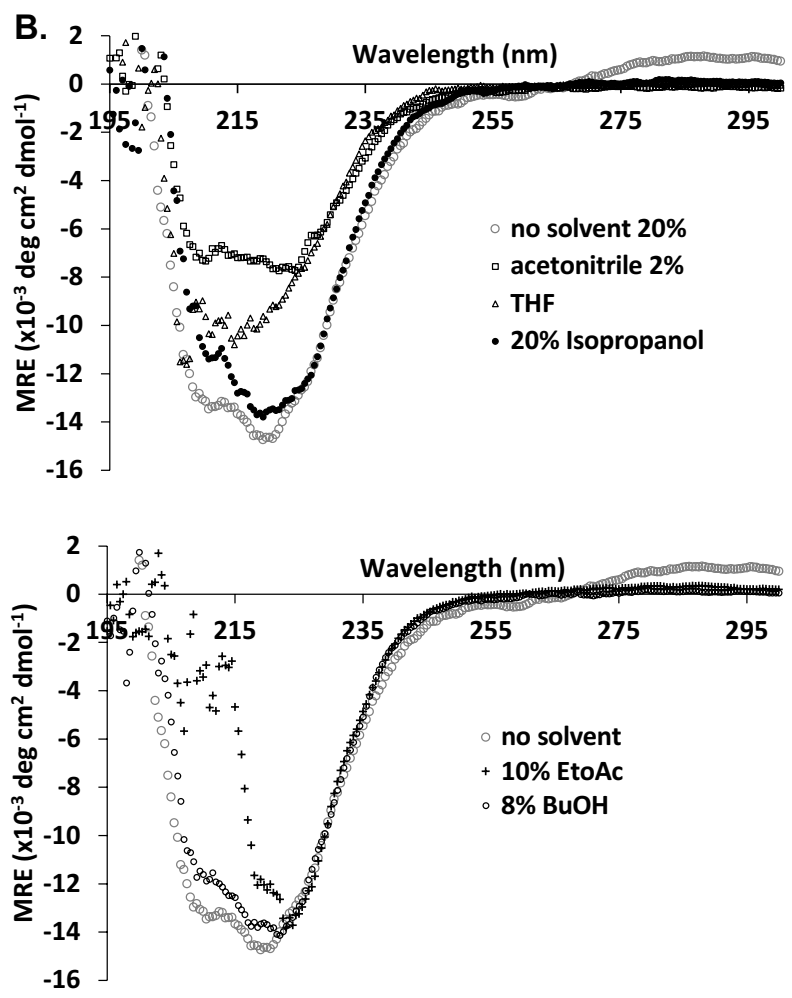
4Figure 5. (A) Time-dependence of circular dichroism mean residue ellipticity at $222 \mathrm{~nm}$, after mixing with co-solvents. (open circle) Apo-TK and (filled circle) holo-TK at $0.5 \mathrm{mg} \mathrm{mL}^{-1}$ in $25 \mathrm{mM}$ Tris-HCl, pH 7.0, were incubated with no solvent, $20 \%(\mathrm{v} / \mathrm{v})$ acetonitrile, $8 \%(\mathrm{v} / \mathrm{v}) \mathrm{n}$-butanol, $10 \%(\mathrm{v} / \mathrm{v})$ ethyl acetate, $20 \%(\mathrm{v} / \mathrm{v})$ isopropanol, or $2 \%$ (v/v) THF. Holo-TK also contained $2.5 \mathrm{mM} \mathrm{MgCl}, 0.25 \mathrm{mM}$ TPP. Error bars represent one standard deviation about the mean $(\mathrm{n}=3)$. (B) Circular dichroism spectra of holo-TK after incubation with organic solvents. Holo-TK $\left(0.5 \mathrm{mg} \mathrm{mL}^{-1}\right)$ in $25 \mathrm{mM}$ Tris- $\mathrm{HCl}, \mathrm{pH} 7.0,2.5 \mathrm{mM} \mathrm{MgCl}_{2}, 0.25 \mathrm{mM}$ TPP, and the presence of (open circle) no solvent; (open square) $20 \%$ acetonitrile; (open circle) $8 \%$ n-butanol (+) $10 \%$ ethyl acetate (filled circle) 20\% isopropanol (open triangle) $2 \%$ THF, was incubated for $3 \mathrm{~h}$ at $25^{\circ} \mathrm{C}$ before full spectra (195-300 nm) were acquired. Error bars represent one standard deviation about the mean $(n=3)$.

\section{Discussion}

The deactivation of both apo-TK and holo-TK by co-solvents generally resulted from a local unfolding event that retained a near-native homodimeric structure. The only exception was for holo-TK in $20 \%(\mathrm{v} / \mathrm{v}) \mathrm{AcCN}$, which induced global unfolding. This is consistent with previous studies that suggest enzyme activity loss in polar solvents is primarily due to the stripping of water from the protein surface and enzyme active-site, which in turn affects the active-site geometry, stability and catalytic function ${ }^{73,74}$. Local unfolding also led to aggregation for holo-TK in certain solvents, but only after enzyme deactivation had already occurred. For holo-TK in AcCN, enzyme inactivation was dominated by global unfolding.

The most hydrophobic co-solvents, with higher $\log (\mathrm{P})$ values, deactivated the enzyme at proportionally lower molar concentrations of co-solvent, although THF appeared to inactivate at lower concentrations than expected from this trend. The $\log (\mathrm{P})$ values also correlated well to the local unfolding rate observed by $\mathrm{CD}$, indicating that the more hydrophobic solvents were better able to unfold the local structure responsible for enzyme deactivation.

Previous studies of other enzymes found that alcohols tend to disrupt tertiary structure and leave the secondary structure interactions largely undisturbed ${ }^{75}$. The data for holo-TK were not entirely consistent with this conclusion, as local changes in secondary structure correlated with activity loss. By contrast, the intrinsic fluorescence indicated little tertiary structure unfolding, whereas the increases in intrinsic fluorescence intensity, and the lag-phases in their kinetics observed for holo- $\mathrm{TK}$ in $\mathrm{PrOH}$ or $\mathrm{nBuOH}$, were most likely due to aggregate formation. However, from CD and DLS measurements, any low levels of aggregate formation were still insufficient to explain the activity loss for TK. More recently, the prolonged exposure to organic solvents was proposed to lead to a decrease in enzyme dynamics and active-site polarity, and also the reorientation of active site residues, which in turn affect the ionization state of the catalytic residues, and hence the stability of transition states and intermediates required for catalysis ${ }^{76}$. However, these mechanisms would be rapidly-reversible effects and so do not readily explain the loss of TK activity which was largely irreversible or at least very slow on the timescale of the activity assays which required a 20 -fold dilution out of the aqueous solvent mixture.

Interestingly, for THF, AcCN, and EtOAc, the more thermodynamically stable holo-TK did not retain more activity than the apo-TK after exposure to these co-solvents, indicating that solvent tolerance was not simply correlated to global conformational stability. However, the local unfolding rates were similar between apo-TK and holo-TK, and so it appears that the local unfolding measured by CD was also not due to unfolding of the cofactor loops, as these are already unstructured in apo-TK. However, the structure of the cofactor loops, and/or presence of bound cofactors adversely influenced the retention of activity. Apo-TK unfolding was found previously to be more reversible than for holo-TK, when refolding TK from urea ${ }^{63}$. If the unfolding of local structure within or close to the active site was more reversible in apo-TK than in holo-TK, then that might explain why the 20 -fold dilution into the reaction assay recovered more activity for apo-TK than for holo-TK.

It was also interesting that only AcCN induced global unfolding, and $\mathrm{CD}$-observable aggregation, and then only in the holo-TK form. AcCN had one of the lowest $\log (\mathrm{P})$ values of the co-solvents tested, and so simple hydrophobicity of the solvent was not the reason. AcCN may be able to form additional interactions with the protein, not found for the other co-solvents, that enable it to unfold the protein more effectively. Alternatively, the apparent unfolding observed by CD may actually also have been due to aggregation, in which case the properties of AcCN promote more irreversible unfolding and aggregation than for the other solvents.

The ideal conditions for biocatalysis in industry require that the enzyme remains active for the duration of the biotransformation. Therefore, even the slow unfolding or aggregation by solvents, as observed for iPrOH, $\mathrm{nBuOH}$ and $\mathrm{AcCN}$ is potentially problematic for longer reactions, or for repeated enzyme use. Considering this, TK was most tolerant in $15 \%(\mathrm{v} / \mathrm{v})(2.0 \mathrm{M}) \mathrm{iPrOH}, 10 \%(\mathrm{v} / \mathrm{v})(1.9 \mathrm{M}) \mathrm{AcCN}$, or $6 \%(\mathrm{v} / \mathrm{v})(0.65 \mathrm{M}) \mathrm{nBuOH}$ as in these cases, the activity remained at $>75 \%$, whereas no aggregation was observed over $3 \mathrm{~h}$.

Finally, this work has provided useful insights that will guide the future engineering of TK and other similarly complex enzymes. Apo-TK and holo-TK differ specifically in the organisation of their cofactor-binding loops. Given their different behaviours in the presence of co-solvents, improvements might be obtained by focusing enzyme engineering within the cofactor-binding loops and neighbouring regions close to the protein surface. A similar strategy was effective previously for the improvement of TK thermostability ${ }^{48,65}$.

\section{Methods}

All chemicals and solvents were obtained from Sigma-Aldrich (Gillingham, UK) unless noted otherwise. 

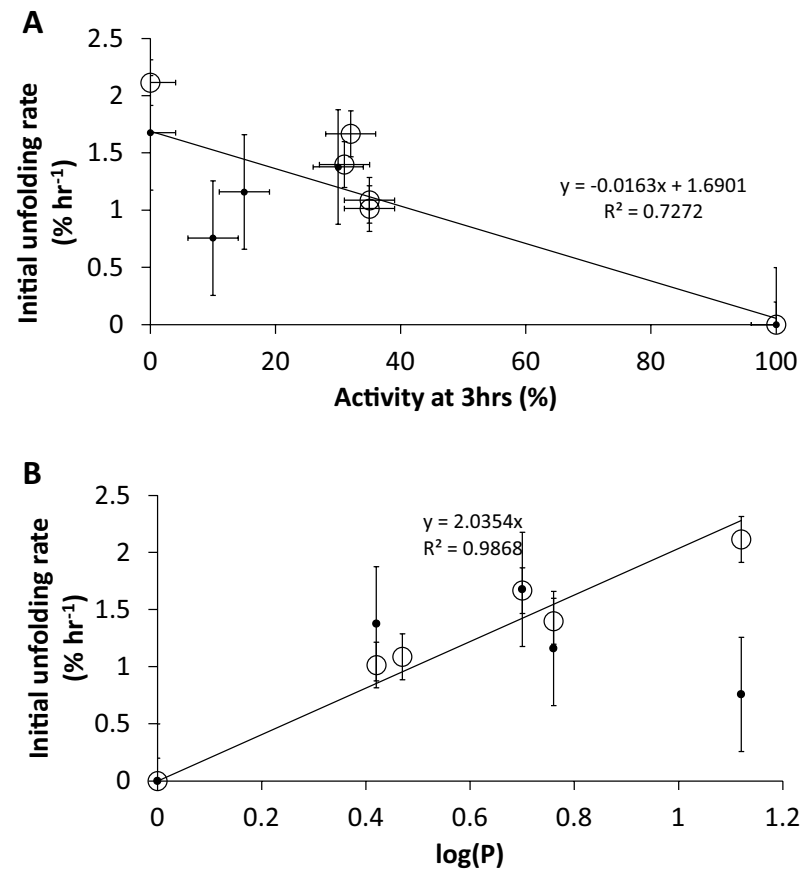

Figure 6. (A,B) Relationship between the local unfolding rate, retained activity after $3 \mathrm{~h}$, and $\log (\mathrm{P})$. Both plots exclude MeCN as this solvent unfolded the protein globally. Apo-TK (open circle) and holo-TK (filled circle) Error bars represent one standard deviation about the mean $(n=3)$.

Expression and purification of transketolase. N-terminally His6-tagged wild-type E. coli transketolase was expressed from E. coli XL10-Gold (Stratagene, La Jolla, CA) containing the engineered plasmid pQR791, purified as described previously ${ }^{63}$, dialysed at $4{ }^{\circ} \mathrm{C}$ for $24 \mathrm{~h}$ against $25 \mathrm{mM}$ Tris- $\mathrm{HCl}, \mathrm{pH} 7.0$, and stored at $4{ }^{\circ} \mathrm{C}$ for a maximum of two weeks without loss of activity, and with no precipitation visible. Protein concentration was determined by absorbance at $280 \mathrm{~nm}$, assuming a monomeric molecular weight (MW) of 72,260.82 $\mathrm{g} \mathrm{mol}^{-1}$ and an extinction coefficient (e) of $93,905 \mathrm{~L} \mathrm{~mol} 1 \mathrm{~cm}^{-163}$. The protein obtained through this overexpression is known to be essentially apo-TK with very low residual activity due to endogenous cofactors ${ }^{64}$.

Residual activities after incubation with organic solvents. Samples were divided into two groups. The first determined the impact of solvents on holo-TK. $40 \mu \mathrm{L}$ of $2.6 \mathrm{mg} \mathrm{mL}^{-1}$ apo-TK (in $125 \mathrm{mM}$ Tris-HCl, $\mathrm{pH}$ 7.0) was mixed with $5 \mu \mathrm{L}$ of a $20 \times$ cofactor stock ( $48 \mathrm{mM} \mathrm{TPP}, 180 \mathrm{mM} \mathrm{MgCl}$ ). This was incubated for $20 \mathrm{~min}$ at $25{ }^{\circ} \mathrm{C}$ with $1000 \mathrm{rpm}$ shaking, before adding $55 \mu \mathrm{L}$ of a range of solvents at different concentrations in water to yield $1 \mathrm{mg} \mathrm{mL}{ }^{-1}$ holo-TK solutions $\left(2.4 \mathrm{mM}\right.$ TPP, $\left.9 \mathrm{mM} \mathrm{MgCl}_{2}\right)$ in $50 \mathrm{mM}$ Tris- $\mathrm{HCl}$, pH 7.0. These solutions were then incubated for $3 \mathrm{~h}$ at $25^{\circ} \mathrm{C} 1000 \mathrm{rpm}$. For the second group, apo-TK solutions received the same treatment as the described above for holo-TK, except that $5 \mu \mathrm{L}$ of water were added instead of the $5 \mu \mathrm{L}$ of the $20 \times$ cofactor stock solution. The activity of the apo-TK was subsequently measured after co-solvent incubation, both in the presence and absence of co-factors, to confirm the low residual activity of the apo-TK.

All residual activities were determined by addition of $15 \mu \mathrm{L}$ enzyme solution samples to $285 \mu \mathrm{L}$ of substrate stock. Substrate stock was in $50 \mathrm{mM}$ Tris-HCl, pH 7.0 for holo-TK experiments and cofactor-free apo-TK experiments, but in $1.05 \times$ cofactors and $50 \mathrm{mM}$ Tris- $\mathrm{HCl}, \mathrm{pH} 7.0$ for apo-TK experiments. These gave final concentrations of $50 \mathrm{mM}$ HPA, $50 \mathrm{mM}$ glycolaldehyde, $2.4 \mathrm{mM}$ TPP ( $0 \mathrm{mM}$ for cofactor-free apo-TK), and $9 \mathrm{mM} \mathrm{MgCl}_{2}$ ( $0 \mathrm{mM}$ for cofactor-free apo-TK), in $50 \mathrm{mM}$ Tris- $\mathrm{HCl}, \mathrm{pH} 7.0$, and 20 -fold dilution of the original solvent. At regular intervals during a period of $90 \mathrm{~min}$, aliquots of $20 \mu \mathrm{L}$ were diluted $1: 10$ with $180 \mu \mathrm{L} 0.1 \%(\mathrm{v} / \mathrm{v})$ TFA, to stop the reactions and then transferred into 96 micro-well plates for measuring of products by HPLC as described previously ${ }^{49}$. Samples were loaded on a $300 \mathrm{~mm}$ Aminex HPX-87H column (Bio-Rad Laboratories) maintained at $60{ }^{\circ} \mathrm{C}$, and analysed with an isocratic flow of $0.1 \%(\mathrm{v} / \mathrm{v})$ TFA in water at $0.6 \mathrm{~mL} \mathrm{~min}{ }^{-1}$.

Secondary structure monitored by circular dichroism (CD). CD spectra (190-300 nm) were recorded on an AVIV $202 \mathrm{SF}$ spectrometer (AVIV Associates, Lakewood, NJ) at $25^{\circ} \mathrm{C}$ using a $1 \mathrm{~mm}$ path length quartz precision cell cuvette. Samples were prepared as above at $0.5 \mathrm{mg} \mathrm{mL}^{-1}$ transketolase both with and without $2.5 \mathrm{mM} \mathrm{MgCl}$ and $0.25 \mathrm{mM}$ TPP for holo-TK and apo-TK respectively, in $25 \mathrm{mM}$ Tris-HCl, $\mathrm{pH} 7.0$, and with the required $\%(\mathrm{v} / \mathrm{v})$ solvent. The lower cofactor concentrations are sufficient for $>90 \%$ saturation of the TK (Miller, 2007), while minimising the dynode voltage in CD spectra due to absorbance by the cofactors. CD spectra were recorded at $0.5 \mathrm{~nm}$ intervals and averaged for $4 \mathrm{~s}$ at each wavelength. Spectra were recorded at $30-45 \mathrm{~min}$ intervals for up to $15 \mathrm{~h}$ after the addition of solvents. Spectra for $25 \mathrm{mM}$ Tris- $\mathrm{HCl}, \mathrm{pH} 7.0$ buffer in 


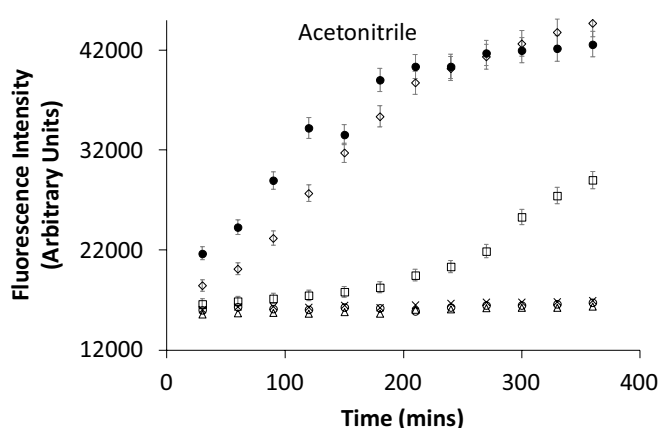

(a)

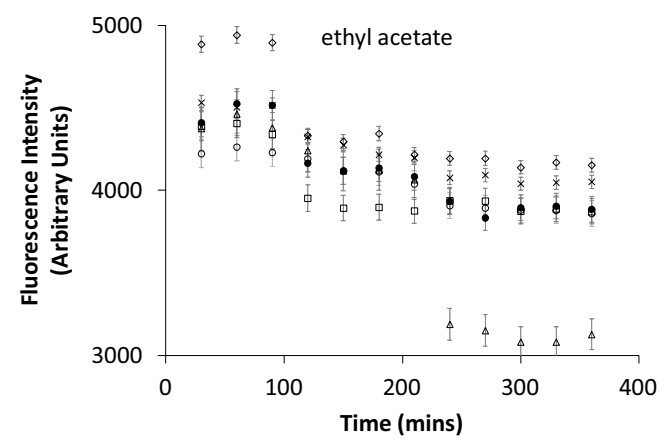

(c)

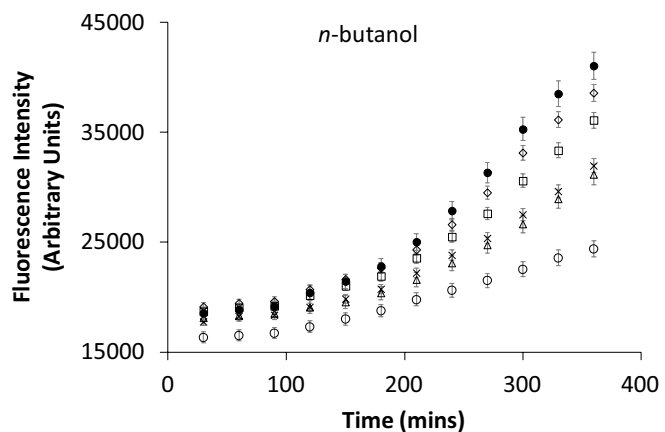

(b)

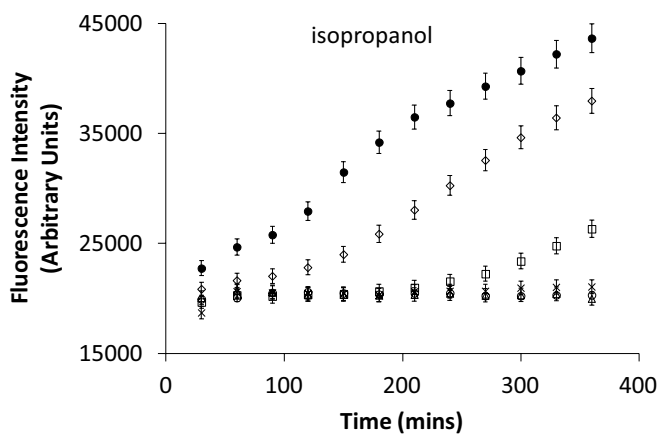

(d)

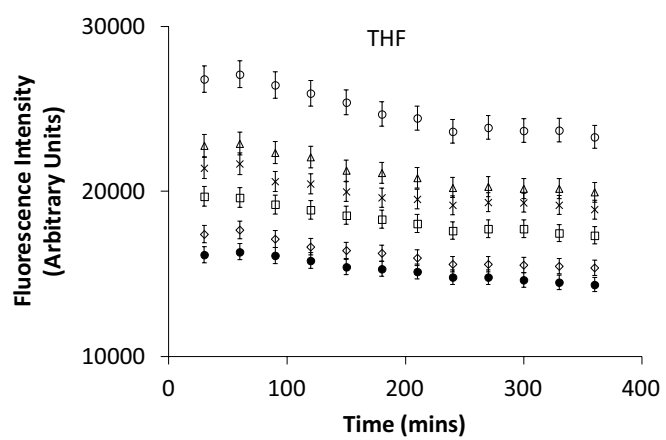

(e)

Figure 7. Time dependence of fluorescence intensity at various organic solvent concentrations for holo-TK. Fluorescence intensity was measured at $340 \mathrm{~nm}$ with excitation at $280 \mathrm{~nm}$. Holo-TK at $0.1 \mathrm{mg} \mathrm{mL}^{-1}$, in $5 \mathrm{mM}$ $\mathrm{MgCl}_{2}, 0.5 \mathrm{mM}$ TPP, $25 \mathrm{mM}$ Tris-HCl, pH 7.0, was measured every $30 \mathrm{~min}$ for $6 \mathrm{~h}$ at $25^{\circ} \mathrm{C}$ in (open circle) $5 \%$, (open triangle) $10 \%,(\mathrm{x}) 15 \%$, (open square) $20 \%$, (open rhombus) $25 \%$ and (filled circle) $30 \%$ (a) acetonitrile (b) $\mathrm{n}$-butanol (c) ethyl acetate (d) isopropanol (e) THF. Error bars represent one standard deviation about the mean $(n=3)$.

the respective $\%(\mathrm{v} / \mathrm{v})$ solvent was subtracted from each recording. Initial rates of structure change were obtained from linear fits to the plots of the CD signal at $222 \mathrm{~nm}$ over time incubated at $25^{\circ} \mathrm{C}$.

Intrinsic fluorescence intensities. Holo- and apo-TK samples were prepared as above at $0.1 \mathrm{mg} \mathrm{mL}^{-1}$

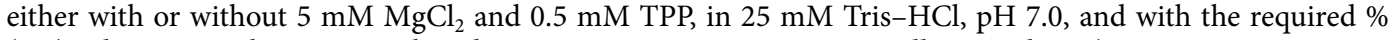
(v/v) solvent. Samples were incubated at $25^{\circ} \mathrm{C}$ in UV transparent 96-well microplates (Costar, Corning Incorporated, NY, USA). Fluorescence intensity was measured every $30 \mathrm{~min}$ for $6 \mathrm{~h}$ from below the plate at $340 \mathrm{~nm}$ emission and $280 \mathrm{~nm}$ excitation using a FLUOstar microplate reader (BMG Labtechnologies Ltd., Aylesbury, UK). Different gain settings were used for the apo-TK and holo-TK experiments. Due to the interference with measurements by an incompatibility of EtOAc with the sample plates that appears after long incubations, those incubations were carried out in glass vials before transferring samples to UV transparent 96-well microplates immediately prior to measurements.

Dynamic light scattering (DLS). The particle size distributions of transketolase in the presence and absence of solvent was measured at $25^{\circ} \mathrm{C}$ with a Zetasizer Nano $\mathrm{S}$ (Malvern Instruments Ltd., UK). Holo-TK at $0.1 \mathrm{mg} \mathrm{mL}{ }^{-1}$ was prepared as above in $25 \mathrm{mM}$ Tris- $\mathrm{HCl}$, pH 7.0, with $0.5 \mathrm{mM}$ TPP and $5 \mathrm{mM} \mathrm{MgCl}_{2}$ and the 


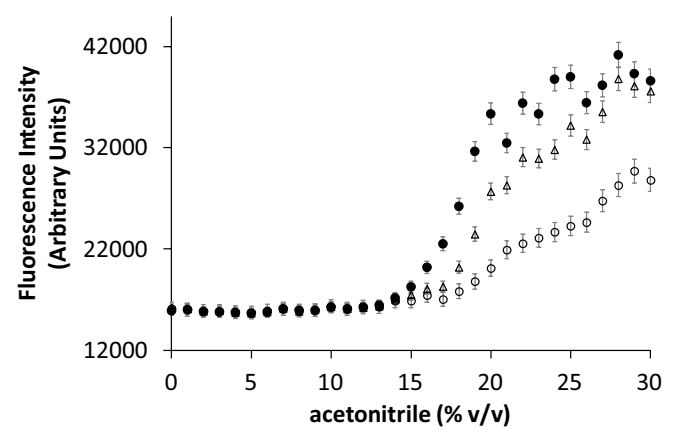

(a)

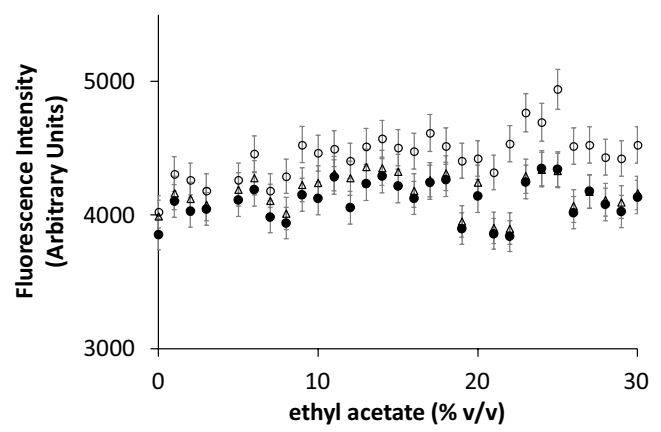

(c)

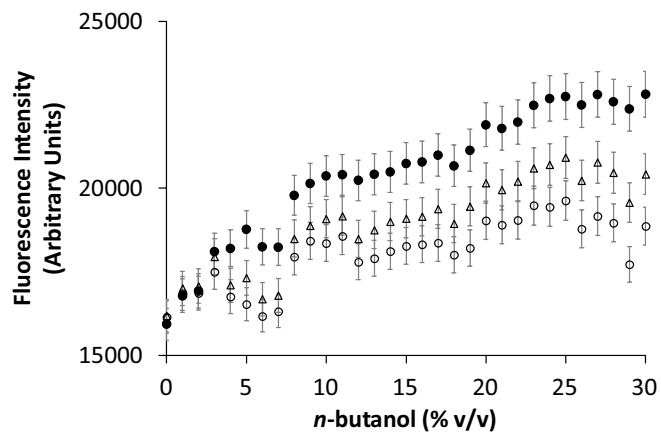

(b)

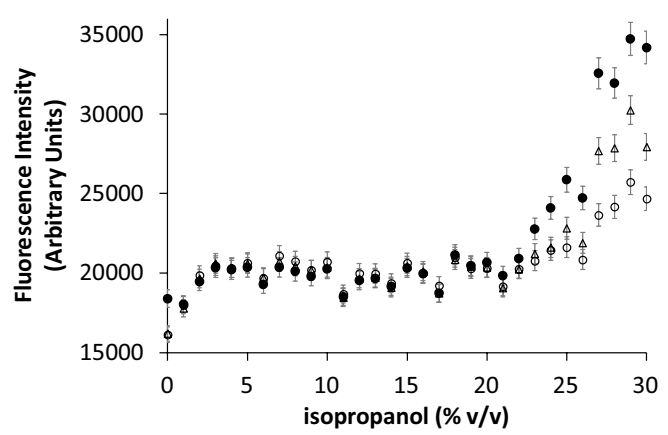

(d)

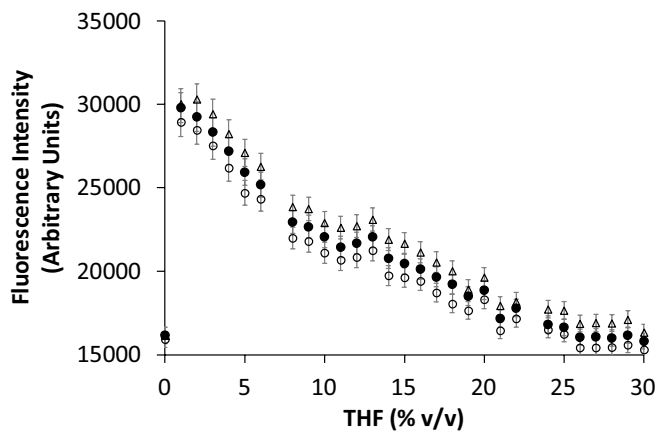

(e)

Figure 8. Fluorescence intensity measurements of apo-TK after incubation with increasing concentrations of organic solvents. Fluorescence intensity was measured at $340 \mathrm{~nm}$ with excitation at $280 \mathrm{~nm}$. Apo-TK at $0.1 \mathrm{mg} \mathrm{mL}^{-1}$ in $25 \mathrm{mM}$ Tris-HCl, pH 7.0 was incubated with (a) acetonitrile (b) n-butanol, (c) ethyl acetate (d) isopropanol (e) THF for (open circle) $1 \mathrm{~h}$, (open triangle) $2 \mathrm{~h}$, (filled circle) $3 \mathrm{~h}$ at $25^{\circ} \mathrm{C}$ prior to measurements. Error bars represent one standard deviation about the mean $(n=3)$.

required \% (v/v) solvent. Samples were incubated for 1, 2 and $3 \mathrm{~h}$ prior to data acquisition. Data were acquired in triplicate, with a $1 \mathrm{~cm}$ path length low volume disposable sizing cuvette. Control samples of the respective buffered solvents, with or without cofactors was subtracted from each recording. The hydrodynamic diameters of each sample were calculated from the averaged measurements using the Zetasizer Nano Series software V.4.20 (Malvern Instruments Ltd., Worcestershire, UK).

Received: 21 September 2021; Accepted: 24 November 2021

Published online: 08 December 2021 


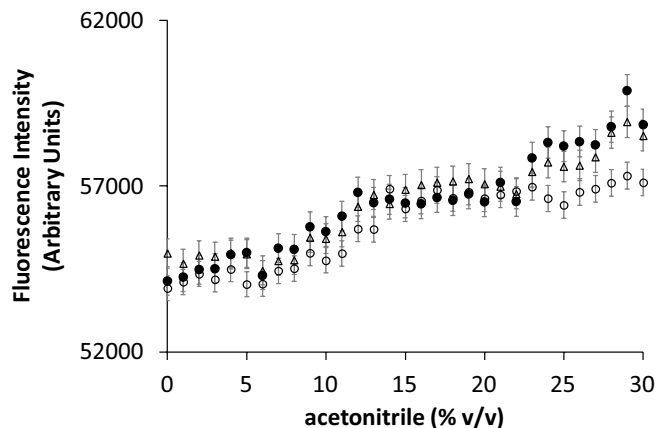

(a)

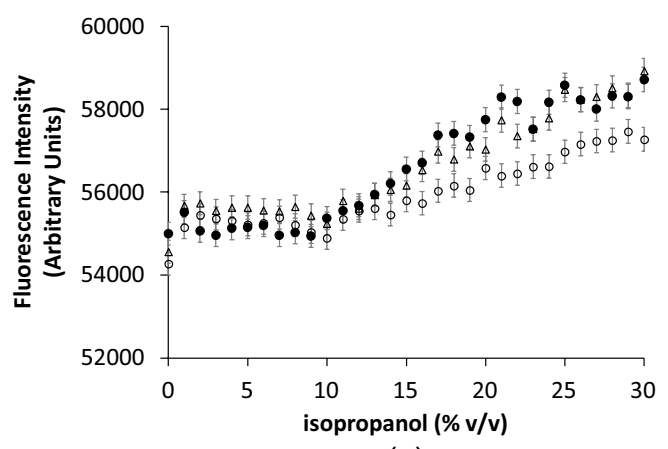

(c)

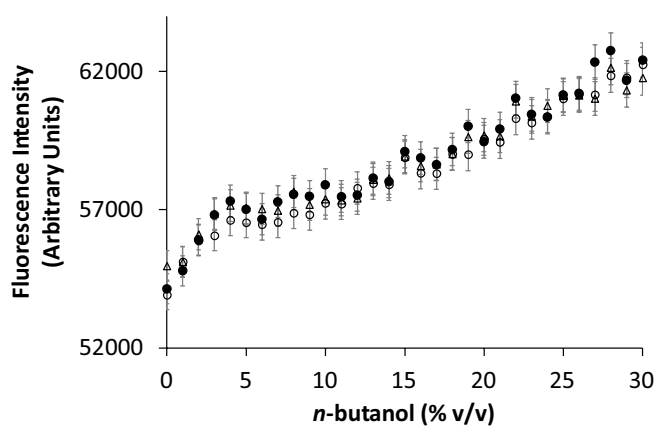

(b)

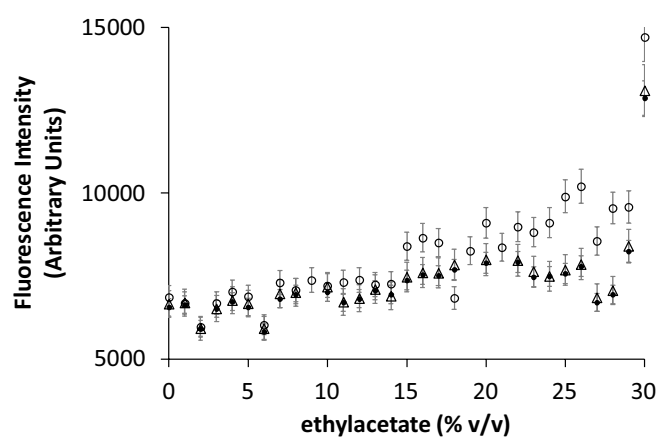

(d)

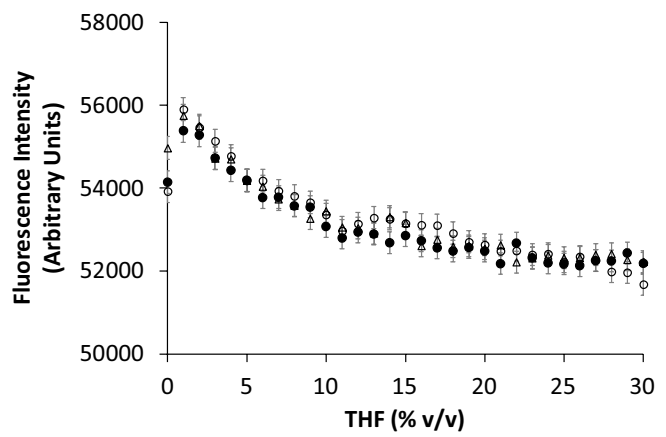

(e)

Figure 9. Fluorescence intensity measurements of holo-TK after incubation with increasing concentrations of organic solvents. Fluorescence intensity was measured at $340 \mathrm{~nm}$ with excitation at $280 \mathrm{~nm}$. Holo-TK at $0.1 \mathrm{mg} \mathrm{mL} \mathrm{mL}^{-1}$ in $5 \mathrm{mM} \mathrm{MgCl}_{2}, 0.5 \mathrm{mM}$ TPP, $25 \mathrm{mM}$ Tris- $\mathrm{HCl}, \mathrm{pH} 7.0$, was incubated with (a) acetonitrile (b) n-butanol (c) ethyl acetate (d) Isopropanol (e) THF for (open circle) $1 \mathrm{~h}$, (open triangle) $2 \mathrm{~h}$, (filled circle) $3 \mathrm{~h} \mathrm{at}$ $25^{\circ} \mathrm{C}$ prior to measurements. Error bars represent one standard deviation about the mean $(n=3)$.

\section{References}

1. Borrelli, M. G. \& Trono, D. Recombinant lipases and phospholipases and their use as biocatalysts for industrial applications. Int. J. Mol. Sci. https://doi.org/10.3390/ijms160920774 (2015).

2. Chen, Y., Xia, N., Liu, Y. \& Wang, P. Efficient biocatalytic preparation of optically pure (R)-1-[4-(trifluoromethyl)phenyl]ethanol by recombinant whole-cell-mediated reduction. Catalysts $\mathbf{9}, 391$ (2019).

3. Fernández-Lucas, J., Castañeda, D. \& Hormigo, D. New trends for a classical enzyme: Papain, a biotechnological success story in the food industry. Trends Food Sci. Technol. 68, 91-101. https://doi.org/10.1016/j.tifs.2017.08.017 (2017).

4. Forti, L. et al. Non-conventional yeasts whole cells as efficient biocatalysts for the production of flavors and fragrances. Molecules https://doi.org/10.3390/molecules200610377 (2015).

5. Min, K., Yeon, Y. J., Um, Y. \& Kim, Y. H. Novel NAD-independent D-lactate dehydrogenases from Acetobacter aceti and Acidocella species MX-AZ02 as potential candidates for in vitro biocatalytic pyruvate production. Biochem. Eng. J. 105, 358-363. https://doi. org/10.1016/j.bej.2015.10.008 (2016).

6. Narancic, T., Davis, R., Nikodinovic-Runic, J. \& O’Connor, K. Recent developments in biocatalysis beyond the laboratory. Biotechnol. Lett. 37, 943-954. https://doi.org/10.1007/s10529-014-1762-4 (2015).

7. Semproli, R., Vaccaro, G. \& Ubiali, D. Use of immobilized amine transaminase from Vibrio fluvialis under flow conditions for the synthesis of (S)-1-(5-fluoropyrimidin-2-yl)-ethanamine. ChemCatChem 12, 1359-1367 (2020).

8. Truppo, M. D. Biocatalysis in the pharmaceutical industry: The need for speed. ACS Med. Chem. Lett. 8, 476. https://doi.org/10. 1021/acsmedchemlett.7b00114 (2017). 
9. Karbalaei-Heidari, H., Shahbazi, M. \& Absalan, G. Characterization of a novel organic solvent tolerant protease from a moderately halophilic bacterium and its behavior in ionic liquids. Appl. Biochem. Biotechnol. 170, 573-586. https://doi.org/10.1007/s12010013-0215-1 (2013).

10. Makshakova, O., Fayzullin, D. \& Zuev, Y. Effect of dioxane molecules on the hydration shell of polypeptides. Russ. J. Bioorganic Chem. 38, 261-265. https://doi.org/10.1134/S1068162012030107 (2012).

11. Mirzaei, M., Khorshahi, H. \& Latifi, A. M. The effect of deep eutectic solvents as co-solvent on organophosphorus hydrolase targeting engineering enzyme-catalyzed. Biointerface Res. Appl. Chem. 10, 6488-6497 (2020).

12. Schweiger, A. K., Rios-Lombardia, N. \& Kourist, R. Using deep eutectic solvents to overcome limited substrate solubility in the enzymatic decarboxylation of bio-based phenolic acids. ACS Sustain. Chem. Eng. 7, 16364-16370 (2019).

13. Denard, C. A., Ren, H. \& Zhao, H. Improving and repurposing biocatalysts via directed evolution. Curr. Opin. Chem. Biol. 25, 55-64. https://doi.org/10.1016/j.cbpa.2014.12.036 (2015).

14. Morris, P., Rios-Solis, L., García-Arrazola, R., Lye, G. J. \& Dalby, P. A. Impact of cofactor-binding loop mutations on thermotolerance and activity of E. coli transketolase. Enzyme Microb. Technol. 89, 85-91. https://doi.org/10.1016/j.enzmictec.2016.04.003 (2016).

15. Stevens, J. C. \& Shi, J. Biocatalysis in ionic liquids for lignin valorization: Opportunities and recent developments. Biotechnol. Adv. 37, 107418 (2019).

16. Widersten, M. Protein engineering for development of new hydrolytic biocatalysts. Curr. Opin. Chem. Biol. 21, 42-47. https://doi. org/10.1016/j.cbpa.2014.03.015 (2014).

17. Börner, T. et al. Three in One: Temperature, Solvent and Catalytic Stability by Engineering the Cofactor-Binding Element of Amine Transaminase. ChemBioChem. 18, 1482-1486. https://doi.org/10.1002/cbic.201700236 (2017).

18. Kong, M., Zhang, Y., Li, Q., Dong, R. \& Gao, H. Kinetics of horseradish peroxidase-catalyzed nitration of phenol in a biphasic system. J. Microbiol. Biotechnol. 27, 297-305. https://doi.org/10.4014/jmb.1607.07039 (2017).

19. Vossenberg, P. et al. Dipeptide synthesis in near-anhydrous organic media: Long-term stability and reusability of immobilized Alcalase. J. Mol. Catal. B Enzym. 93, 23-27. https://doi.org/10.1016/j.molcatb.2013.03.014 (2013).

20. $\mathrm{Wu}, \mathrm{L}$. D., Rathi, B. \& Han, G. Characterization of immobilized tyrosinase - an enzyme that is stable in organic solvent at 100 degrees C. RSC Adv. 8, 39529-39535 (2018).

21. Klibanov, A. M. Improving enzymes by using them in organic solvents. Nature 409, 241. https://doi.org/10.1038/35051719 (2001).

22. Lotti, M., Pleiss, J., Valero, F. \& Ferrer, P. Effects of methanol on lipases: Molecular, kinetic and process issues in the production of biodiesel. Biotechnol. J. 10, 22-30. https://doi.org/10.1002/biot.201400158 (2015).

23. Merino, M. E. D., Lancioni, C. \& Castells, C. B. Chiral separation of several pesticides on an immobilized amylose tris(3-chloro5-methylphenylcarbamate) column under polar-organic conditions. Influence of mobile phase and temperature on enantioselectivity. J. Chromatogr. 1624, 461240 (2020).

24. Duboué-Dijon, E. et al. Coupled valence-bond state molecular dynamics description of an enzyme-catalyzed reaction in a nonaqueous organic solvent. J. Phys. Chem. B 121, 7027-7041. https://doi.org/10.1021/acs.jpcb.7b03102 (2017).

25. Mohtashami, M., Fooladi, J., Haddad-Mashadrizeh, A., Housaindokht, M. R. \& Monhemi, H. Molecular mechanism of enzyme tolerance against organic solvents: Insights from molecular dynamics simulation. Int. J. Biol. Macromol. 122, 914-923 (2019).

26. Stepankova, V. et al. Strategies for stabilization of enzymes in organic solvents. ACS Catal. 3, 2823-2836. https://doi.org/10.1021/ cs400684x (2013).

27. Badoei-Dalfard, A., Khajeh, K., Asghari, S. M., Ranjbar, B. \& Karbalaei-Heidari, H. R. Enhanced activity and stability in the presence of organic solvents by increased active site polarity and stabilization of a surface loop in a metalloprotease. J. Biochem. 148, $231-238(2010)$

28. Paggiola, G., Hunt, A. J., Mcelroy, C. R., Sherwood, J. \& Clark, J. H. Biocatalysis in bio-derived solvents: An improved approach for medium optimisation. Green Chem. 16, 2107-2110. https://doi.org/10.1039/c3gc42526f (2014).

29. Sinha, R. \& Khare, S. Effect of organic solvents on the structure and activity of moderately halophilic Bacillus sp. EMB9 protease. Extremophiles 18, 1057-1066. https://doi.org/10.1007/s00792-014-0683-4 (2014).

30. Ahmad, S., Kamal, M. Z., Sankaranarayanan, R. \& Rao, N. M. Thermostable Bacillus subtilis lipases. In vitro evolution and structural insight. J. Mol. Biol. 381, 324-340. https://doi.org/10.1016/j.jmb.2008.05.063 (2008).

31. Ahmad, S., Kumar, V., Ramanand, K. B. \& Rao, N. M. Probing protein stability and proteolytic resistance by loop scanning: A comprehensive mutational analysis. Protein Sci. 21, 433-446. https://doi.org/10.1002/pro.2029 (2012).

32. Mukherjee, J. \& Gupta, M. N. Protein aggregates: Forms, functions and applications. Int. J. Biol. Macromol. 97, 778-789. https:// doi.org/10.1016/j.ijbiomac.2016.11.014 (2017).

33. Diener, M., Kopka, B., Pohl, M., Jaeger, K.-E. \& Krauss, U. Fusion of a coiled-coil domain facilitates the high-level production of catalytically active enzyme inclusion bodies. ChemCatChem 8, 142-152. https://doi.org/10.1002/cctc.201501001 (2016).

34. Gupta, S. Comparative study on hydrolysis of oils by lipase immobilized biocatalytic PS membranes using biphasic enzyme membrane reactor. J. Environ. Chem. Eng. 4, 1797-1809. https://doi.org/10.1016/j.jece.2016.03.007 (2016).

35. Konieczny, S., Krumm, C., Doert, D., Neufeld, K. \& Tiller, J. C. Investigations on the activity of poly(2-oxazoline) enzyme conjugates dissolved in organic solvents. J. Biotechnol. 181, 55-63. https://doi.org/10.1016/j.jbiotec.2014.03.035 (2014).

36. Fei, H., Xu, G., Wu, J.-P. \& Yang, L.-R. Improving the acetaldehyde tolerance of DERASEP by enhancing the rigidity of its protein structure. J. Mol. Catal. B Enzym. 116, 148-152. https://doi.org/10.1016/j.molcatb.2015.03.017 (2015).

37. Illanes, A., Cauerhff, A., Wilson, L. \& Castro, G. R. Recent trends in biocatalysis engineering. Bioresour. Technol. 115, 48-57. https:// doi.org/10.1016/j.biortech.2011.12.050 (2012).

38. Das, S., Zhao, L. J. \& Finn, M. G. Enzyme stabilization by virus-like particles. Biochemistry 59, 2870-2881 (2020).

39. Kochetov, G. A., Philippov, P. P., Razjivin, A. P. \& Tikhomirova, N. K. Kinetics of reconstruction of holo-transketolase. FEBS Lett. 53, 211-212. https://doi.org/10.1016/0014-5793(75)80021-4 (1975).

40. Sundström, M., Lindqvist, Y. \& Schneider, G. Three-dimensional structure of apotransketolase flexible loops at the active site enable cofactor binding. FEBS Lett. 313, 229-231. https://doi.org/10.1016/0014-5793(92)81197-T (1992).

41. Turner, N. J. Applications of transketolases in organic synthesis. Curr. Opin. Biotechnol. 11, 527-531. https://doi.org/10.1016/ S0958-1669(00)00140-3 (2000).

42. Hecquet, L., Bolte, J. \& Demuynck, C. Enzymatic synthesis of "natural-labeled" 6-deoxy-L-sorbose precursor of an important food flavor. Tetrahedron 52, 8223-8232. https://doi.org/10.1016/0040-4020(96)00379-1 (1996).

43. Hecquet, L., Lemaire, M., Bolte, J. \& Demuynck, C. Chemo-enzymatic synthesis of precursors of fagomine and 1,4-dideoxy1,4-imino-D-arabinitol. Tetrahedron Lett. 35, 8791-8794. https://doi.org/10.1016/S0040-4039(00)78499-1 (1994).

44. Lindqvist, Y., Schneider, G., Ermler, U. \& Sundström, M. Three-dimensional structure of transketolase, a thiamine diphosphate dependent enzyme, at 2.5 A resolution. EMBO J. 11, 2373-2379 (1992).

45. Shaeri, J., Wright, I., Rathbone, E. B., Wohlgemuth, R. \& Woodley, J. M. Characterization of enzymatic D-xylulose 5-phosphate synthesis. Biotechnol. Bioeng. 101, 761-767. https://doi.org/10.1002/bit.21949 (2008).

46. Woodley, J. M., Mitra, R. K. \& Lilly, M. D. Carbon-carbon bond synthesis. Ann. N. Y. Acad. Sci. 799, 434-445. https://doi.org/10. 1111/j.1749-6632.1996.tb33238.x (1996).

47. Affaticati, P. E. et al. Structural analysis of an evolved transketolase reveals divergent binding modes. Sci. Rep. 6, 35716 (2016).

48. Yu, H., Yan, Y., Zhang, C. \& Dalby, P. A. Two strategies to engineer flexible loops for improved enzyme thermostability. Sci. Rep. 7, 41212. https://doi.org/10.1038/srep41212 (2017). 
49. Hibbert, E. G. et al. Directed evolution of transketolase activity on non-phosphorylated substrates. J. Biotechnol. 131, 425-432. https://doi.org/10.1016/j.jbiotec.2007.07.949 (2007).

50. Subrizi, F. et al. Transketolase catalysed upgrading of L-arabinose: The one-step stereoselective synthesis of L-gluco-heptulose. Green Chem. 18, 3158-3165 (2016).

51. Cázares, A. et al. Non- $\alpha$-hydroxylated aldehydes with evolved transketolase enzymes. Org. Biomol. Chem. 8, 1301-1309. https:// doi.org/10.1039/b924144b (2010).

52. Hibbert, E. G. et al. Directed evolution of transketolase substrate specificity towards an aliphatic aldehyde. J. Biotechnol. 134, 240-245. https://doi.org/10.1016/j.jbiotec.2008.01.018 (2008).

53. Strafford, J. et al. Directed evolution to re-adapt a co-evolved network within an enzyme. J. Biotechnol. 157, 237-245. https://doi. org/10.1016/j.jbiotec.2011.11.017 (2012).

54. Galman, J. L. et al. $\alpha, \alpha^{\prime}$-Dihydroxyketone formation using aromatic and heteroaromatic aldehydes with evolved transketolase enzymes. Chem. Commun. 46, 7608. https://doi.org/10.1039/c0cc02911d (2010).

55. Smith, M. E. B., Hibbert, E. G., Jones, A. B., Dalby, P. A. \& Hailes, H. C. Enhancing and reversing the stereoselectivity of Escherichia coli transketolase via single-point mutations. Adv. Synth. Catal. 350, 2631-2638. https://doi.org/10.1002/adsc.200800489 (2008).

56. Casajus, H. et al. Enzymatic synthesis of aliphatic acyloins catalyzed by thermostable transketolase. ChemCatChem 22, 5772-5779 (2020).

57. Zabar, J. A. et al. Engineering a thermostable transketolase for unnatural conversion of (2S)-hydroxyaldehydes. Adv. Synth. Catal. 8, 1715-1720 (2015).

58. Rios-Solis, L. et al. A toolbox approach for the rapid evaluation of multi-step enzymatic syntheses comprising a "mix and match" E. coli expression system with microscale experimentation. Biocatal. Biotransform. 29, 192-203 (2011).

59. Rios-Solis, L. et al. Modelling and optimisation of the one-pot, multi-enzymatic synthesis of chiral amino-alcohols based on microscale kinetic parameter determination. Chem. Eng. Sci. 122, 360-372. https://doi.org/10.1016/j.ces.2014.09.046 (2015).

60. Payongsri, P., Steadman, D., Hailes, H. C. \& Dalby, P. A. Second generation engineering of transketolase for polar aromatic aldehyde substrates. Enzyme Microb. Technol. 71, 45-52. https://doi.org/10.1016/j.enzmictec.2015.01.008 (2015).

61. Yu, H. et al. Engineering transketolase to accept both unnatural donor and acceptor substrates and produce a-hydroxyketones. FEBS. J. 287, 1758-1776. https://doi.org/10.1111/febs.15108 (2019).

62. Jahromi, R. R. F., Morris, P., Martinez-Torres, R. J. \& Dalby, P. A. Structural stability of E. coli transketolase to temperature and pH denaturation. J. Biotechnol. 155, 209-216. https://doi.org/10.1016/j.jbiotec.2011.06.023 (2011).

63. Martinez-Torres, R. J., Aucamp, J. P., George, R. \& Dalby, P. A. Structural stability of E. coli transketolase to urea denaturation. Enzyme Microb. Technol. 41, 653-662. https://doi.org/10.1016/j.enzmictec.2007.05.019 (2007).

64. Miller, O., Hibbert, E., Ingram, C., Lye, G. \& Dalby, P. Optimisation and evaluation of a generic microplate-based HPLC screen for transketolase activity. Biotechnol. Lett. 29, 1759-1770. https://doi.org/10.1007/s10529-007-9435-1 (2007).

65. Yu, H. \& Dalby, P. A. Exploiting correlated molecular-dynamics networks to counteract enzyme activity-stability trade-off. Proc. Natl. Acad. Sci. USA 115, E12192-E12200. https://doi.org/10.1073/pnas.1812204115 (2018).

66. Esakova, O. et al. Effect of transketolase substrates on holoenzyme reconstitution and stability. Biochemistry 70, 770-776. https:// doi.org/10.1007/s10541-005-0182-4 (2005).

67. Altshuller, A. P. \& Everson, H. E. The solubility of ethyl acetate in water. J. Am. Chem. Soc. 75, 1727 (1953).

68. Magnusson, A. O. et al. NanoDSF as screening tool for enzyme libraries and biotechnology development. FEBS J. 286, 184-204 (2019).

69. Zhou, Y. et al. A novel strategy to improve the aromatic alcohols tolerance of enzyme for preparative-scale synthesis of natural glycosides. Catal. Commun. 102, 9-12 (2017).

70. Littlechild, J. et al. Crystallization and preliminary X-ray crystallographic data with Escherichia coli transketolase. Acta Crystallogr. Sect. D Biol. Crystallogr. 51, 1074-1076. https://doi.org/10.1107/S0907444995005415 (1995).

71. Aucamp, J. P., Martinez-Torres, R. J., Hibbert, E. G. \& Dalby, P. A. A microplate-based evaluation of complex denaturation pathways: Structural stability of Escherichia coli transketolase. Biotechnol. Bioeng. 99, 1303-1310. https://doi.org/10.1002/bit.21705 (2008).

72. Li, Y., Ogunnaike, B. A. \& Roberts, C. J. Multi-variate approach to global protein aggregation behavior and kinetics: Effects of pH, $\mathrm{NaCl}$, and temperature for $\boldsymbol{\alpha}$-chymotrypsinogen A. J. Pharm. Sci. 99, 645-662. https://doi.org/10.1002/jps.21869 (2010).

73. Prasad, B. V. L. S. \& Suguna, K. Role of water molecules in the structure and function of aspartic proteinases. Acta Crystallogr. Sect. D Biol. Crystallogr. 58, 250-259. https://doi.org/10.1107/S0907444901018327 (2002).

74. Simon, L. M., Kotormán, M., Szabó, A., Nemcsók, J. \& Laczkó, I. The effects of organic solvent/water mixtures on the structure and catalytic activity of porcine pepsin. Process Biochem. 42, 909-912. https://doi.org/10.1016/j.procbio.2007.01.014 (2007).

75. Babu, K. R., Moradian, A. \& Douglas, D. J. The methanol-induced conformational transitions of $\beta$-lactoglobulin, cytochrome c, and ubiquitin at low $\mathrm{pH}$ : A study by electrospray ionization mass spectrometry. J. Am. Soc. Mass Spectrom. 12, 317-328. https:// doi.org/10.1016/S1044-0305(00)00226-9 (2001).

76. Bansal, V. et al. Effect of prolonged exposure to organic solvents on the active site environment of subtilisin Carlsberg. J. Mol. Catal. B. Enzym. 64, 38-44. https://doi.org/10.1016/j.molcatb.2010.01.021 (2010).

77. Sangster, J. Octanol-water partition coefficients of simple organic compounds. J. Phys. Chem. Ref. Data 18, 1111 (1989).

\section{Acknowledgements}

The Royal Thai Government is acknowledged for the support of Phattaraporn Morris. The Mexican National Council for Science and Technology (CONACYT) is acknowledged for the support of Ribia García-Arrazola. The UK Engineering and Physical Sciences Research Council (EPSRC) is thanked for the support of the multidisciplinary Biocatalysis Integrated with Chemistry and Engineering (BiCE) programme (GR/S62505/01) at University College London (London, UK).

\section{Author contributions}

P.M. and R.G.A. carried out experimental procedures, unless stated otherwise. P.M., R.G.A., L.R.S. and P.A.D. wrote the main manuscript text and prepared all figures. P.A.D. conceived and coordinated the study. All authors reviewed the manuscript.

\section{Competing interests}

The authors declare no competing interests.

\section{Additional information}

Supplementary Information The online version contains supplementary material available at https://doi.org/ 10.1038/s41598-021-03001-8. 
Correspondence and requests for materials should be addressed to P.A.D.

Reprints and permissions information is available at www.nature.com/reprints.

Publisher's note Springer Nature remains neutral with regard to jurisdictional claims in published maps and institutional affiliations.

(c) (i) Open Access This article is licensed under a Creative Commons Attribution 4.0 International cc) License, which permits use, sharing, adaptation, distribution and reproduction in any medium or format, as long as you give appropriate credit to the original author(s) and the source, provide a link to the Creative Commons licence, and indicate if changes were made. The images or other third party material in this article are included in the article's Creative Commons licence, unless indicated otherwise in a credit line to the material. If material is not included in the article's Creative Commons licence and your intended use is not permitted by statutory regulation or exceeds the permitted use, you will need to obtain permission directly from the copyright holder. To view a copy of this licence, visit http://creativecommons.org/licenses/by/4.0/.

(C) The Author(s) 2021 